OPEN ACCESS

Edited by:

Basem Moosa,

King Abdullah University of Science and Technology, Saudi Arabia

Reviewed by:

Roland Christian Fischer,

Graz University of Technology, Austria

Rami Suleiman,

King Fahd University of Petroleum and

Minerals, Saudi Arabia

*Correspondence:

Mostafa A. Hussien maabdulaal@kau.edu.sa

Specialty section:

This article was submitted to Inorganic Chemistry,

a section of the journal

Frontiers in Chemistry

Received: 21 December 2020

Accepted: 01 February 2021

Published: 15 June 2021

Citation:

Sharfalddin AA, Emwas A-H, Jaremko M and Hussien MA (2021)

Practical and Computational Studies of

Bivalence Metal Complexes of

Sulfaclozine and Biological Studies.

Front. Chem. 9:644691.

doi: $10.3389 /$ fchem.2021.644691

\section{Practical and Computational Studies of Bivalence Metal Complexes of Sulfaclozine and Biological Studies}

\author{
Abeer A Sharfalddin ${ }^{1}$, Abdul-Hamid Emwas ${ }^{2}$, Mariusz Jaremko ${ }^{3}$ and Mostafa A. Hussien ${ }^{1,4 *}$ \\ ${ }^{1}$ Department of Chemistry, Faculty of Science, King Abdulaziz University, Jeddah, Saudi Arabia, ${ }^{2}$ King Abdullah University of \\ Science and Technology (KAUST), Thuwal, Saudi Arabia, ${ }^{3}$ King Abdullah University of Science and Technology (KAUST), \\ Biological and Environmental Science and Engineering (BESE), Thuwal, Saudi Arabia, ${ }^{4}$ Department of Chemistry, Faculty of \\ Science, Port Said University, Port Said, Egypt
}

In the search for novel, metal-based drug complexes that may be of value as anticancer agents, five new transition metal complexes of sulfaclozine (SCZ) with $\mathrm{Cu}(\mathrm{II}), \mathrm{Co}(\mathrm{II}), \mathrm{Ni}(\mathrm{II})$, $\mathrm{Zn}(\mathrm{II})$, and Fe(II) were successfully synthesized. The chemical structure of each complex was characterized using elemental analysis $(\mathrm{CHN})$, IR spectroscopy, UV-Vis spectroscopy, thermogravimetric analysis (TGA), and electronic paramagnetic resonance (EPR) spectroscopy. IR spectra indicated that the donor atoms were one sulfonyl oxygen atom and one pyrazine nitrogen atom, which associated with the metal ions to form a stable hexagonal coordination ring. The metal-ligand stability constant $\left(\mathrm{K}_{\mathrm{f}}\right)$ revealed that $\mathrm{Cu}(\mathrm{II})$ and $\mathrm{Ni}(\mathrm{II})$ have good coordination stability among the metal compounds. Theoretical studies using DFT/B3LYP were performed to further validate the proposed structures. The obtained results indicated that $\mathrm{Cu}(\mathrm{II})$ has a trigonal bipyramidal geometry, whereas $\mathrm{Fe}(\mathrm{II}), \mathrm{Co}(\mathrm{II})$, and $\mathrm{Ni}(\mathrm{II})$ have an octahedral structure, while $\mathrm{Zn}(\mathrm{II})$ has a tetrahedral arrangement. The bio-activities of the characterized complexes were evaluated using DNA binding titration and molecular docking. The binding constant values for the metal complexes were promising, with a maximum value for the copper metal ion complex, which was $9 \times 10^{5} \mathrm{M}^{-1}$. Molecular docking simulations were also carried out to evaluate the interaction strength and properties of the synthesized metal complexes with both DNA and selected cancer-relevant proteins. These results were supported by in vitro cytotoxicity assays showing that the $\mathrm{Cu}(\mathrm{II})$ and $\mathrm{Ni}(\mathrm{II})$ complexes display promising antitumor activity against colon and breast cancer cell lines.

Keywords: electronic paramagnetic resonance analysis, DFT, sulfaclozine, molecular docking, anticancer

\section{INTRODUCTION}

Sulfonamide is a well-known antibacterial compound that has been in use for around 50 years (Stober and DeWitte, 1982). It came to prominence when Domagk et al. reported that Prontosil, a sulfamidochrysoidine azo dye, was reduced to the antibiotic sulfonamide and triamine benzene in living cells (Domagk, 1935), with sulfonamide being the affected part in this dye molecule. Metal ions have played key roles as components of pharmaceuticals in the field of anticancer therapy (Wong and Giandomenico, 1999), arthritis (Roberts et al., 1996), and cardiovascular medicine (Navarro et al., 2004). Thus, searching for novel metal-based drug complexes is a high priority for medicinal biochemists. 


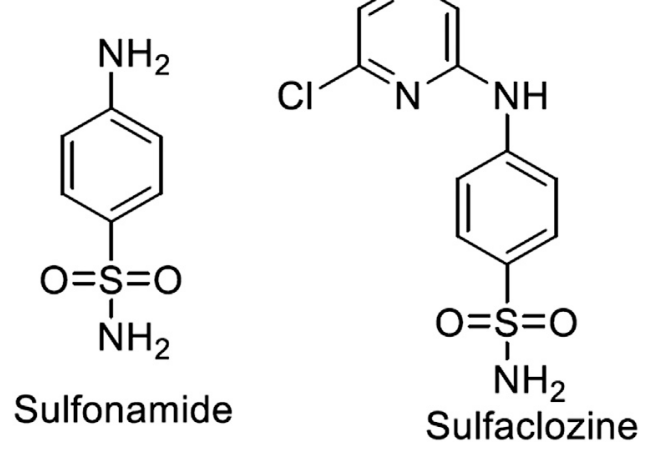

FIGURE 1 | Structures of sulfonamide and sulfaclozine.

Metal complexes of sulfonamide drugs, Figure 1, have drawn attention from the scientific community because of their superior clinical applications compared to the free drugs. For instance, the zinc sulfadiazine complex has a 1:2 molar ratio and is used to promote wound healing and control infections (Fox, 1977). Additionally, the $\operatorname{Ag}(\mathrm{I})$ sulfadiazine complex is utilized as a topical antibacterial agent for treating first-, second-, and third-degree burns (Carr et al., 1973). Due to the effectiveness of sulfonamide metal complexes in the clinic, a diversity of metal complexes, metals based on sulfonamide or its derivative compounds, with transition metals, $\mathrm{Cu}(\mathrm{II}), \mathrm{Co}(\mathrm{II})$, and $\mathrm{Ni}(\mathrm{II})$ (Ajibade et al., 2006; Rocha et al., 2019), or with transition metals of platinum group, Pt(II), Pd(II) (Ajibade et al., 2013), and $\mathrm{Ru}$ (III) (Refat et al., 2016), or with heavy metals (Khedr and Saad, 2015), have been obtained to enhance their antimicrobial properties (Ajibade et al., 2006; Rocha et al., 2019).

Sulfaclozine (SCZ), Figure 1, is a derivative of the sulfonamide drug in which an amide group ( $\mathrm{NH}$ ) binds to a chloropyrazine aromatic ring. It is used as an oral antibiotic to treat various poultry diseases (Şentepe and Eraslan, 2010) and murine toxoplasmosis (Zeng et al., 2012; Ismail et al., 2016). Interestingly, it has several potential binding sites that could be coordinated with metal ions, namely, two pyrazine nitrogen atoms, sulfonyl oxygen atoms, and sulfonamide nitrogen atoms and an amino group at its tail. In addition, the chloropyrazine ring in SCZ could enhance its biological properties more than sulfonamide.

To the best of our knowledge, no published reports have described the complexation between divalent transition metals and SCZ. In this work, a new synthesis of metal complexes in ethanol solution was performed. The molecular structures of all the new complexes were characterized by analytical, spectroscopic, and thermal techniques. The structures of the prepared complexes were optimized by DFT with the exchange-correlation functional approach (B3LYP) to study the geometric arrangement around the metal ions. Moreover, the energy gap calculated from the HOMO and LUMO was used to predict the biological properties. Experimentally, various techniques were carried out to investigate the potential influence of the metal ion coordination on their potential as therapeutics. One of the least expensive and simplest methods is spectroscopic titration experiments with CT-DNA to study binding affinity of the metal complexes with the pharmacological target. A molecular docking approach was also used to examine the molecular interaction of the newly synthesized compounds and the free ligand to test their inhibitory capacity toward different cancer proteins. A previous study tested the inhibitory effect of sulfonamide and its derivatives on a selected cancer cell line (Refat et al., 2016). Hence, in this work, in vitro cytotoxicity assays using two cell lines, a breast cancer cell line (MCF-7) and a colon cancer cell line (CaCo-2), were used to evaluate all compounds.

\section{MATERIALS AND METHODS}

\section{Chemicals and Reagents}

Sulfaclozine (SCZ) of $99 \%$ purity was purchased from Aldrich. The metal chlorides were obtained from Fisher Scientific. Solvents and analytical reagents were commercially obtained from the $\mathrm{BDH}$ chemical company and used as received.

\section{Synthesis of Metal Complexes}

The appropriate ratio of metal chlorides of $\mathrm{Cu}(\mathrm{II}), \mathrm{Co}(\mathrm{II}), \mathrm{Zn}$ (II), $\mathrm{Fe}(\mathrm{II})$, and $\mathrm{Ni}(\mathrm{II})$ of $1.0 \mathrm{mmol}$ volume in $20 \mathrm{ml}$ ethyl alcohol was added to the SCZ ligand $(2.0 \mathrm{mmol}$ in $30 \mathrm{ml}$ ethyl alcohol). The mixed solution was placed on a hot plate at $80^{\circ} \mathrm{C}$ for $2-3 \mathrm{~h}$ with continuous stirring and refluxing until the color precipitates formed. The resulting solution was allowed to evaporate at room temperature, and the solids were washed with diethyl ether and dried under vacuum.

\section{The Molar Ratio Method and the Metal Sulfaclozine Stability Constants Procedure}

The stoichiometric composition of the complexes in ethanol was determined by the molar relation method (Davila et al., 2012). The concentration of the metal ion was kept constant $\left(0.36 \times 10^{-4}\right.$ $\mathrm{M})$, and the concentration of the SCZ ligand varied from [L] = 0.18 to $1.25 \times 10^{-4} \mathrm{M}$. The solutions were stabilized at $25.0^{\circ} \mathrm{C}$ for $10 \mathrm{~min}$ to let the reaction reach equilibrium. Next, the spectra were recorded in the Shimadzu UV/Vis spectrometer with a cell width of $1 \mathrm{~cm}$ optical path length, in the $200-500 \mathrm{~nm}$ range.

The metal-ligand stability constant $\left(\mathrm{K}_{\mathrm{f}}\right)$ of the complexes was calculated using the following equilibrium equation:

$$
\begin{gathered}
{[M]+2[\mathrm{SCZ}] \leftrightarrow\left[\mathrm{ML}_{2}\right]} \\
K_{f}=\left(\frac{\left[\mathrm{ML}_{2}\right]}{[\mathrm{M}] \times[\mathrm{L}]^{2}}\right)=\left(\frac{\left[\mathrm{ML}_{2}\right]}{\left(C_{M}-\left[\mathrm{ML}_{2}\right]\right) \times\left(C_{L}-2\left[\mathrm{ML}_{2}\right]\right)^{2}}\right) .
\end{gathered}
$$

Using Beer's law $(A=\varepsilon b c)$, the equation can be rewritten for the stability constants of complexes (Panhwar and Memon, 2012; Samsonowicz and Regulska, 2017) as

$$
K_{f}=\left(\frac{A / \varepsilon}{\left(C_{M}-A / \varepsilon\right) \times\left(C_{L}-2 A / \varepsilon\right)^{2}}\right),
$$


where $\mathrm{A}$ is the measured absorbance and $\varepsilon$ is the molar absorption coefficient.

\section{Structure Analysis}

The micro-analytical ratio analyses $(\mathrm{C}, \mathrm{H}$, and $\mathrm{N})$ were carried out in a PerkinElmer CHN 2400 elemental analyzer. The molar conductance of the metal complexes in the DMF solvent $\left(10^{-3} \mathrm{M}\right)$ was measured on a Hach conductivity meter model. A Bruker infrared spectrophotometer was utilized to record the infrared spectra of the ligand and its complex in the range of $400-4000 \mathrm{~cm}^{-1}$. An electronic spectroscopic study of SCZ and the metal compounds in DMSO solution with a concentration of $10^{-3} \mathrm{M}$ was obtained by the Shimadzu UV/Vis spectrometer in the range of 200-1100 $\mathrm{nm}$. The electron paramagnetic resonance study for the solid sample was recorded on a Bruker EMX PLUS spectrometer using the $\mathrm{X}$ band frequency $(9.5 \mathrm{GHz})$ using reported experimental details (Alahmari et al., 2019; Alghrably et al., 2019). The content of metal ions was calculated gravimetrically as metal oxides. The TG-DTG experiment was conducted using the Mettler Toledo STARe software. All experiments were under air at a flow rate of $30 \mathrm{ml} / \mathrm{min}$ and a heating rate of $10^{\circ} \mathrm{C} / \mathrm{min}$ starting from $25^{\circ} \mathrm{C}$ and ending at $800^{\circ} \mathrm{C}$ using a single loose top loop. The percentage of metal ions was calculated gravimetrically as metal oxides. Magnetic measurements of metal complexes were measured at room temperature using Gouy's method by a magnetic susceptibility balance from the Johnson Matthey and Sherwood model.

\section{Computational Details}

The initial molecular geometries of SCZ and the metal complexes were optimized in the gas phase using the Gaussian 09W (Frisch et al., 2009) program package employing hybrid DFT/B3LYP at 6-31G (d,p) level for the free ligand and LAND for the metal complexes. The frequencies calculated were followed by optimization to ensure that the obtained structures were in the minima energy state. The GaussView molecular visualization program (Dennington et al., 2016) was used to visualize the input files and extract the HOMO-LUMO energies. The reactivity descriptors: chemical potential $(\mu)$, global hardness $(\eta)$, chemical softness $(S)$, and electrophilicity $(\omega)$, were calculated using the following formulas (Sharfalddina et al., 2020a):

$$
\begin{aligned}
\mu & =-\left(E_{\mathrm{LUMO}}-\mathrm{E}_{\mathrm{HOMO}} / 2\right), \\
\eta & =-\left(\mathrm{E}_{\mathrm{LUMO}}-\mathrm{E}_{\mathrm{HOMO}} / 2\right), \\
\mathrm{S} & =1 / 2 \eta, \\
\omega & =\pi 2 / 2 \eta \mathrm{R} .
\end{aligned}
$$

\section{Bio-Activity Analysis DNA Binding Methodology}

The DNA binding protocol is reported in our previous work (Alsaeedi et al., 2020; Sharfalddina et al., 2020b). Compounds were dissolved in DMSO at room temperature with a fixed concentration that had absorbances between 1 and 1.2. The CT-DNA stock solution was prepared in a buffer solution $(\mathrm{pH}=7.4)$ and kept at $5^{\circ} \mathrm{C}$ for 1 week. The ratio absorbance for the stock at $280-290 \mathrm{~nm}$ was 1.8 (nucleotide to protein) indicating DNA is free of protein (Arjmand and Jamsheera, 2011). The molar absorption coefficient of $6600 \mathrm{M}^{-1} \mathrm{~cm}^{-1}$ and the absorbance at $260 \mathrm{~nm}$ for CT-DNA were used to determine the DNA concentration (Tabassum et al., 2014; Mashat et al., 2019), which was $1.21 \times 10^{-4} \mathrm{M}$. The experiments were performed by keeping the compound concentration constant and varying the DNA concentration from $1.69 \times 10^{-6}$ to 5.55 $\times 10^{-6} \mathrm{M}$. The mixture solutions were allowed to incubate for $30 \mathrm{~min}$ at RT before recording the absorption. The binding constant was computed by the Wolfe-Shimer equation (Zehra et al., 2019) given as follows:

$$
[\mathrm{DNA}] /\left(\varepsilon_{\mathrm{a}}-\varepsilon_{\mathrm{f}}\right)=[\mathrm{DNA}] /\left(\varepsilon_{\mathrm{b}}-\varepsilon_{\mathrm{f}}\right)+1 / K_{\mathrm{b}}\left(\varepsilon_{\mathrm{a}}-\varepsilon_{\mathrm{f}}\right),
$$

where $[\mathrm{DNA}]=$ concentration of CT-DNA in base pairs. $\varepsilon_{\mathrm{a}}=$ extinction coefficient observed for $\mathrm{A}_{\mathrm{obs}} /$ [compound] at the given DNA concentration.

$\varepsilon_{\mathrm{f}}=$ extinction coefficient of the free compound in solution. $\varepsilon_{\mathrm{b}}=$ extinction coefficient of the compound when binding to DNA.

$K_{b}=$ ratio of the slope to the intercept of the plot [DNA]/ $\left(\epsilon_{\mathrm{a}}-\epsilon_{\mathrm{f}}\right)$ versus [DNA].

$\mathrm{K}_{\mathrm{b}}$ values were obtained by plotting the left side of the equation vs. DNA concentration and then calculating the ratio of the slope and intercept. The following equation was used to calculate Gibb's free energy values:

$\Delta \mathrm{G}=-\mathrm{RT} \ln \mathrm{K}_{\mathrm{b}}$, where $\mathrm{R}=8.314 \mathrm{JK}^{-1} \mathrm{~mol}^{-1}$ and $\mathrm{T}=298 \mathrm{~K}$.

\section{Molecular Docking}

High-resolution crystallographic structures of proteins included in this study, breast cancer $(\mathrm{PDB}$ code $=1 \mathrm{hK} 7)$ and colon cancer ( $\mathrm{PDB}$ code $=4 \mathrm{FM} 9)$ receptors, were downloaded from the Protein Data Bank into MOE software 2015 (MOE (The Molecular Operating Environment), 2015). The docking protocol is reported in our previous work (Abdel-Rhman et al., 2019). Protein preparation started with removing water molecules and co-ligand. The site finder was used to find the possible binding sites in the protein, and then the $3 \mathrm{D}$ protonation process was carried out to correct and fix the protein. The 3D structures of the compounds were minimized through the MMFF94X Force Field and optimized to obtain the lowest energy conformation with the best geometry using a gradient of 0.001 . The docking parameters were the triangle matcher method for placing the compound and London dG for scoring and GBVI/WSA dG for rescoring. The ranking affinity of the ligand and metal compounds toward the amide protein was calculated using binding free energy and hydrogen bonds between the ligand and the amino acid. The measured hydrogen bond did not exceed the length of 3.1-3.7 $\mathrm{A}^{\circ}$.

\section{Antitumor Assay}

A human colon cancer cell line (CaCo-2) and human breast cancer cell line (MCF-7) were obtained from the VACSERA Tissue Culture Collection Unit. The propagation was done in Dulbecco's modified Eagle's medium (DMEM) completed with heat-inactivated fetal bovine serum (10\%), 1\% HEPES buffer, 
TABLE 1 | Analytical and physical data of SCZ and metal complexes.

\begin{tabular}{|c|c|c|c|c|c|c|c|c|}
\hline \multirow[t]{2}{*}{ Metal complex } & \multirow[t]{2}{*}{ M.Wt. } & \multirow[t]{2}{*}{ Color } & \multicolumn{4}{|c|}{ Elemental analysis, \% found (calc.) } & \multirow[t]{2}{*}{$\Lambda_{\mathrm{m}}\left(\Omega \mathrm{cm}^{2} \mathrm{~mol}^{-1}\right)$} & \multirow[t]{2}{*}{ Melting point } \\
\hline & & & $\mathrm{C} \%$ & $\mathbf{N} \%$ & $\mathbf{S} \%$ & $\mathbf{M} \%$ & & \\
\hline \multirow[t]{2}{*}{ SCZ } & 250.05 & White & 47.99 & 22.39 & 12.31 & - & 1.3 & 130 \\
\hline & & & 48 & 22.40 & 12.30 & & & \\
\hline \multirow[t]{2}{*}[\mathrm{Cu}(\mathrm{SCZ})_{2}\mathrm{Cl}]{$\mathrm{Cl}$} & 635 & Yellow ochre & 34.13 & 15.92 & 9.10 & 9.09 & 94 & 170 \\
\hline & & & 34.10 & 15.95 & 9.12 & 9.03 & & \\
\hline \multirow[t]{2}{*}[\mathrm{Co}(\mathrm{SCZ})_{2}\mathrm{ClOH}_{2}]{$\mathrm{Cl}$} & 628.39 & Blue & 34.35 & 15.89 & 10.17 & 9.35 & 70 & 205 \\
\hline & & & 34.32 & 15.89 & 10.20 & 8.50 & & \\
\hline \multirow[t]{2}{*}[\mathrm{Ni}(\mathrm{SCZ})_{2}\mathrm{Cl}_{2}]{} & 630.15 & Light green & 34.36 & 15.99 & 9.17 & 8.40 & 5.56 & 200 \\
\hline & & & 34.40 & 16.05 & 9.19 & 8.41 & & \\
\hline \multirow[t]{2}{*}[\mathrm{Fe}(\mathrm{SCZ})_{2}\mathrm{Cl}_{2}]{} & 627.30 & Dark brown & 34.52 & 16.10 & 9.21 & 8.02 & 1.56 & 158 \\
\hline & & & 34.51 & 15.92 & 9.25 & 8.00 & & \\
\hline \multirow[t]{2}{*}[\mathrm{Zn}(\mathrm{SCZ})_{2}]{$\mathrm{Cl}_{2}$} & 636.83 & Sandy & 34.04 & 15.60 & 9.09 & 9.26 & 152 & 214 \\
\hline & & & 34.02 & 15.55 & 9.10 & 9.30 & & \\
\hline
\end{tabular}

L-glutamine, and gentamicin $\left(50^{\circ} \mu \mathrm{g} / \mathrm{ml}\right)$. Next, in a humidified atmosphere with $5 \%$ carbon dioxide, the cells were kept at $37^{\circ} \mathrm{C}$ and were sub-cultured two times a week. The determination of sample cytotoxicity on cells (MTT protocol) was performed as reported (Alley et al., 1988; Van de Loosdrecht et al., 1994). $1 \times$ $10^{5}$ cells $/ \mathrm{ml}(100 \mu \mathrm{l} /$ well $)$ were incubated in a 96-well tissue culture plate at $37^{\circ} \mathrm{C}$ for $24 \mathrm{~h}$ to create a complete monolayer sheet. After an aggregate sheet of cells was formed, the monolayer cells were separated from the growth medium and washed twice with wash media. $2 \%$ of serum as a maintenance medium was used to dilute the tested sample twofold in the RPMI medium. A constant volume $(0.1 \mathrm{ml})$ of each diluted sample was added simultaneously in various wells in the maintenance medium at $37^{\circ} \mathrm{C}$, with three wells without treatment used as control cells. The samples were checked for any physical signs of toxicity such as partial or complete loss of the monolayer every $24 \mathrm{~h}$. The MTT protocol depends on tetrazolium salt reduction from yellow to purple by metabolically viable cells. Therefore, $20 \mu \mathrm{l}$ of the solution (5 $\mathrm{mg} / \mathrm{ml}$ in $\mathrm{PBS}$ ) was added to each well and maintained $\left(37^{\circ} \mathrm{C}, \quad 5 \% \quad \mathrm{CO}_{2}\right)$ for $1-5 \mathrm{~h}$ until the cell metabolization process was completed. After drying the wells by dumping the media, $200 \mu \mathrm{l}$ DMSO was added to re-suspend the MTT metabolic product and was mixed thoroughly. The spectrophotometric absorbance at OD $=560 \mathrm{~nm}$ was measured and then subtracted from the background sample $(50 \mu \mathrm{L}$ MTT + $50 \mu \mathrm{L}$ of media) at $620 \mathrm{~nm}$.

The percentage of cell survival was calculated as follows:

$$
\text { Survival fraction }=\frac{\text { O.D. }(\text { treated cells })}{\text { O.D. }(\text { controlled cells })} \times 100 \text {. }
$$

Each experiment was repeated three times to obtain a linear relationship between optical density and cell quantity.

\section{RESULTS AND DISCUSSION}

\section{Analytical Data of the Metal Complexes}

The analytical data and physical properties of the ligand and its metal complexes are summarized in Table 1. The isolated colored solid complexes are stable at room temperature, except for the $\mathrm{Zn}$ (II) complex, which turned light brown due to the absorption of water molecules over time. Moreover, they are soluble in DMF and DMSO. The molar conductance of $\mathrm{Cu}$ (II) and $\mathrm{Co}$ (II) at $10^{-3} \mathrm{M}$ in DMF had values fall in the 66-95 $\Omega$ $\mathrm{cm}^{2} \mathrm{~mol}^{-1}$ range, indicating the presence of two ion types in the solution, which are 1:1 of cationic and anionic species (Ali et al., 2013). The zinc complex showed a higher value, $152 \Omega$ $\mathrm{cm}^{2} \mathrm{~mol}^{-1}$, suggesting two $\mathrm{Cl}^{-}$ions out of the coordination sphere. In contrast, for $\mathrm{Ni}(\mathrm{II})$ and $\mathrm{Fe}(\mathrm{II})$, the molecular conductance was too low to account for any dissociation to $\mathrm{Cl}^{-}$ions; thus, they are non-electrolytes.

\section{Stoichiometry and Metal-Ligand Stability Constant}

The collected absorption is plotted toward the ratio of $[\mathrm{M}] /$ $[\mathrm{M}]+[\mathrm{L}]$ and presented in Supplementary Figure S1 for the metallic complexes. The reflection line upon increasing the ligand concentration was around 0.33 and revealed that one mole of the metal reacted with two moles of the ligand.

The obtained values of $\mathrm{K}_{\mathrm{f}}$ by the previous equations were in the order $\mathrm{Zn}-\mathrm{SCZ}\left(1.74 \times 10^{-5}\right)>\mathrm{Cu}-\mathrm{SCZ}\left(1.47 \times 10^{-5}\right)>$ $\mathrm{Ni}-\mathrm{SCZ}\left(0.48 \times 10^{-5}\right)>\mathrm{Fe}-\mathrm{SCZ}\left(0.25 \times 10^{-5}\right)>\mathrm{Co}-\mathrm{SCZ}$ $\left(0.17 \times 10^{-5}\right)$ and showed good interaction of $\mathrm{Zn}(\mathrm{II})$ and $\mathrm{Cu}(\mathrm{II})$ ions forming a stable coordination complex.

\section{Infrared Spectroscopy}

The comparison spectra of the free ligand and the five metal complexes are illustrated in Supplementary Figure S2, and the essential bands are given in Supplementary Table S1. The divalent metal complexes had similar infrared spectra to their SCZ drug, and thus, careful observation of peak shift was performed. The $\mathrm{NH}_{2}$ stretching appeared at $3295-2966 \mathrm{~cm}^{-1}$ for asymmetric and symmetric modes, respectively, maintained in the same range for all complexes. As a consequence of the hydrogen bonding interaction between the $\mathrm{NH}_{2}$ and $\mathrm{SO}_{2}$ groups, a significant shift to higher frequencies (Rocha et al., 2019) was observed for those bands. Moreover, the $\mathrm{NH}_{2}$ binding at $1682 \mathrm{~cm}^{-1}$ was 


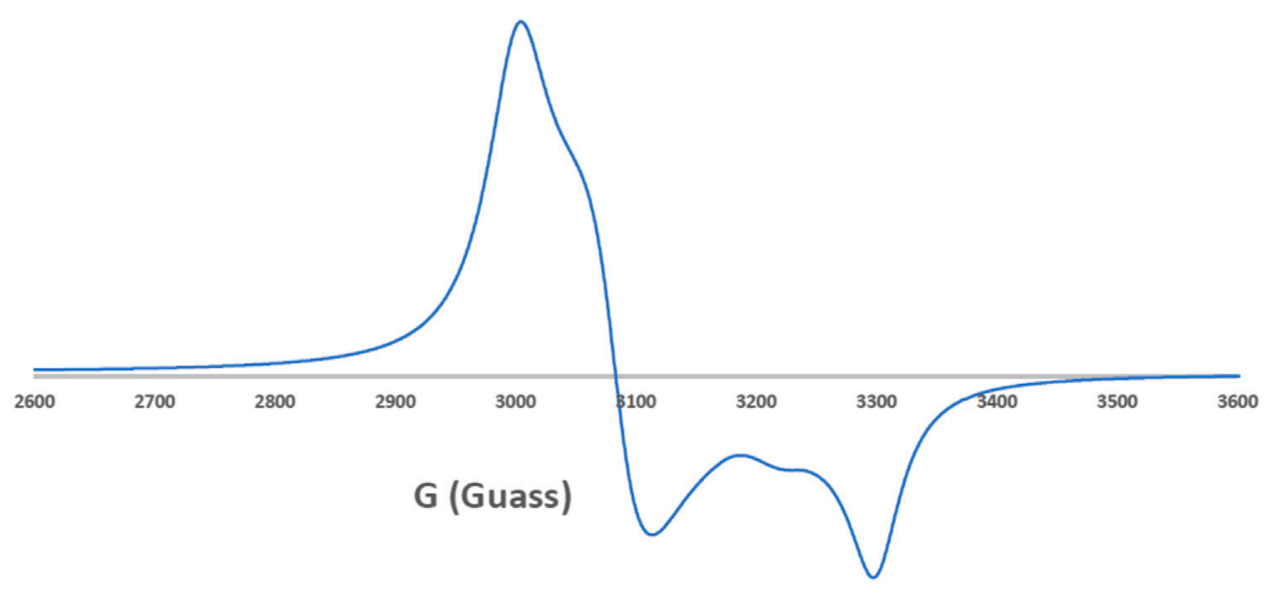

FIGURE 2 | EPR spectrum of the Cu-SCZ complex.

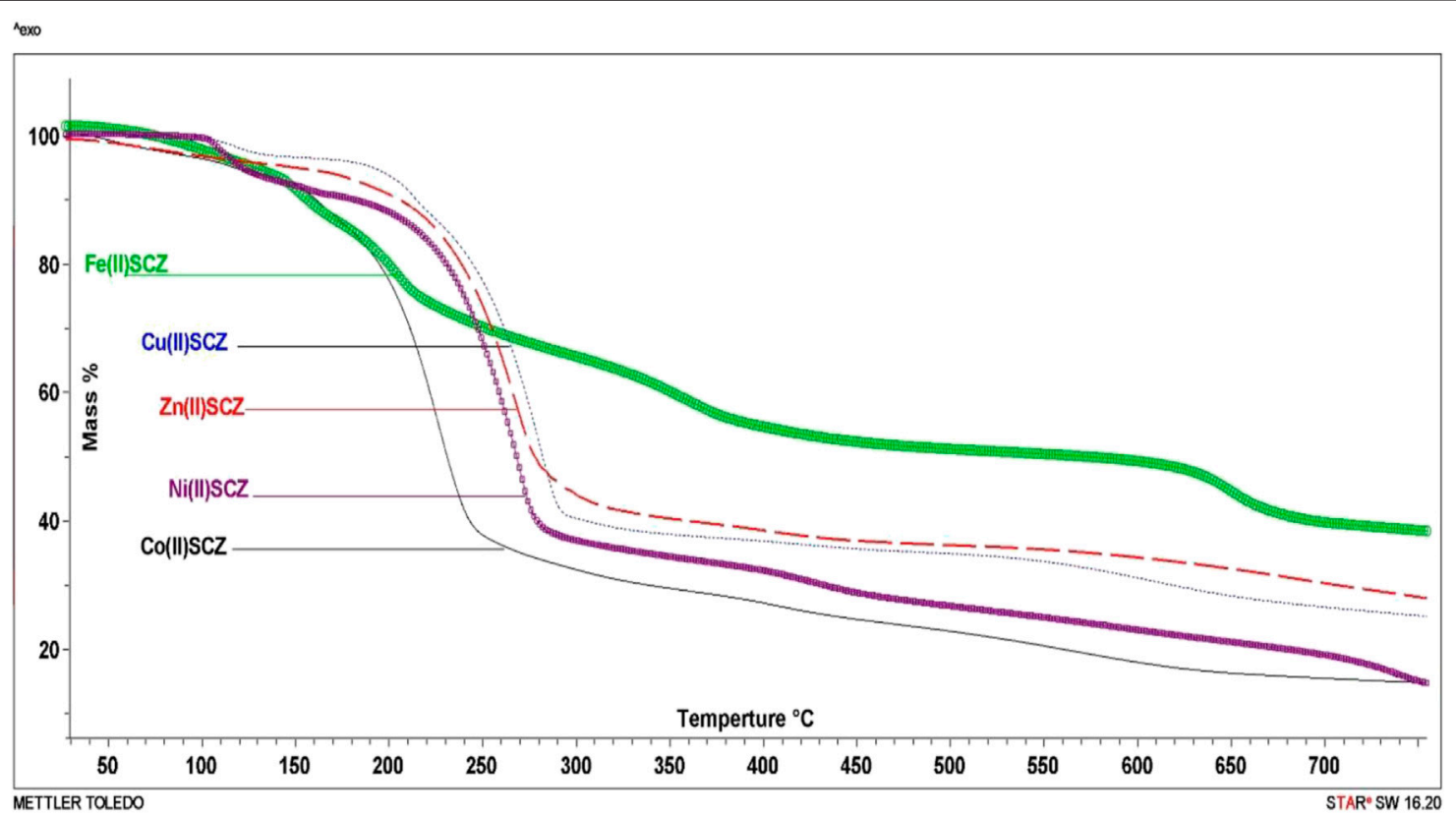

FIGURE 3 | TG curves of $\left[\mathrm{Cu}(\mathrm{SCZ})_{2} \mathrm{Cl}\right] \mathrm{Cl} \cdot 2 \mathrm{H}_{2} \mathrm{O},\left[\mathrm{Co}(\mathrm{SCZ})_{2} \mathrm{ClOH}_{2}\right] \mathrm{Cl}_{2} 2 \mathrm{H}_{2} \mathrm{O}$, $\left[\mathrm{Ni}\left(\mathrm{SCZ}_{2} \mathrm{Cl}_{2}\right] \cdot 2 \mathrm{H}_{2} \mathrm{O},\left[\mathrm{Zn}(\mathrm{SCZ})_{2}\right] \mathrm{Cl}_{2} \cdot 2 \mathrm{H}_{2} \mathrm{O}\right.$, and $\left.\left[\mathrm{Fe}(\mathrm{SCZ})_{2} \mathrm{Cl}\right]_{2}\right] \cdot 2 \mathrm{H}_{2} \mathrm{O}$ complexes.

preserved in the metal spectra, which revealed this assignment is not coordinated to the metal. Another donating atom group is the oxygen atoms of the $\mathrm{SO}_{2}$ group, which could be associated with the metal center. There is noticeable disappearing for the symmetric $\mathrm{SO}_{2}$ at $1149 \mathrm{~cm}^{-1}$ or redshift for asymmetric stretching modes at $1344 \mathrm{~cm}^{-1}$ indicating the coordination of the sulfonamide oxygen to the metal ion. The intensity bands corresponding to the C $=\mathrm{N}$ group in the pyrazine ring at 1580,1512 , and $1433 \mathrm{~cm}$ ${ }^{1}$ (Stober and DeWitte, 1982) shifted slightly after coordination to the metal concerning those of the free ligand, thus proving that $\mathrm{N}_{4}$ pyridine associated with the complexation to form a hexagon ring. The assignment of the $\mathrm{M}-\mathrm{O}$ and $\mathrm{M}-\mathrm{N}$ stretching modes in the metal complex spectra was indicated by the lowintensity band in the ranges $742-600 \mathrm{~cm}^{-1}$ and $420-400 \mathrm{~cm}^{-1}$, respectively.

\section{Electronic Paramagnetic Resonance Analysis for the $\mathrm{Cu}$ (II) Complex}

EPR spectroscopy is a selective method where only unpaired electron species can be detected, while all other parts of the studied molecules are EPR silent. Thus, EPR spectroscopy is a powerful approach to study the formation of organic radicals (Mattar et al., 2002) and monitor the coordination of paramagnetic transition metals such as the $\mathrm{Cu}(\mathrm{II})$ and 
TABLE 2 | Electronic parameters of the metal complexes.

\begin{tabular}{|c|c|c|c|c|c|c|c|}
\hline \multirow{2}{*}{$\begin{array}{l}\text { Compound } \\
\text { SCZ }\end{array}$} & \multicolumn{2}{|c|}{$\mathbf{V}_{\text {ligand band shift }}$} & \multirow[t]{2}{*}{ V3 } & \multirow{2}{*}{$\begin{array}{c}\text { V2 } \\
-\end{array}$} & \multirow{2}{*}{$\begin{array}{c}\text { 10Dq } \\
-\end{array}$} & \multirow[t]{2}{*}{ B } & \multirow[t]{2}{*}{$\beta$} \\
\hline & 274(36500) & 313(31500) & & & & & \\
\hline$\left[\mathrm{Cu}(\mathrm{SCZ})_{2} \mathrm{Cl}\right] \mathrm{Cl}$ & 275(36400) & $321(31200)$ & & $810(12346)$ & 12350 & - & - \\
\hline$\left[\mathrm{Co}(\mathrm{SCZ})_{2} \mathrm{ClOH}_{2}\right] \mathrm{Cl}$ & 278(36000) & $315(31500)$ & 589(16977) & $685(14600)$ & 7770 & 708 & 0.730 \\
\hline$\left[\mathrm{Ni}(\mathrm{SCZ})_{2} \mathrm{Cl}_{2}\right]$ & 297(25189) & 405(24700) & $680(14700)$ & $760(12900)$ & 5400 & 760 & 0.738 \\
\hline$\left[\mathrm{Fe}(\mathrm{SCZ})_{2} \mathrm{Cl}_{2}\right]$ & 276 & 335(29900) & - & - & - & - & - \\
\hline
\end{tabular}

Mn(II) complexes (Emwas et al., 2013; Haque et al., 2019). In this study, we employed EPR spectroscopy to study the ligand coordination of the $\left[\mathrm{Cu}(\mathrm{SCZ})_{2} \mathrm{Cl}\right] \mathrm{Cl}$ complex. The solid EPR presented in Figure 2 shows two peaks with different g-values: the one with parallel orientation with term gll and the other with perpendicular orientation with term $g \perp$, which was higher than the last one $(g \perp=2.189>g \|=2.044)$. This value suggested a compression on the $Z$ axial and $a$ pentacoordinate arrangement strongly shifted toward the trigonal bipyramid (Kozlevčar, 2008), with a $\mathrm{Cl}^{-}$atom and two oxygen atoms from two different ligand molecules in the equatorial plane and two nitrogen atoms in the axial position. The ground state will be ${ }^{2} \mathrm{~A}_{1 \mathrm{~g}}$, which is a combination of $\mathrm{d} z^{2}$ and $\mathrm{d} x^{2}-y^{2}$ orbitals (Garribba and Micera, 2006; Lakshmi et al., 2012). Moreover, the nature of binding to the SCZ ligand was calculated by $g_{a v}=(g \|+2 \mathrm{~g} \perp) / 3$ (Ibrahim et al., 2015) and was $2.14<2.3$, which indicated a highly covalent character of the metal-ligand bond.

\section{Electronic Spectroscopic and Magnetic Susceptibility}

The UV-Vis spectroscopic analysis was performed for the ligand and the metal complexes in DMSO in the range of 200-900 nm, Supplementary Figure S3. The bands at $276 \mathrm{~nm}$ of both ligand and complex spectra can be assigned to an $n \rightarrow \pi$ transition. Moreover, a band between 300 and $400 \mathrm{~nm}$ was observed in the free ligand for the $\pi \rightarrow \pi^{*}$ transition of the aromatic ring (Zhao et al., 1992) and shifted to a higher frequency in all metal complexes, confirming the coordination to the aromatic pyrazine ring (Yang et al., 2005). There is a peak at low energy in the range 10, $500-14,600 \mathrm{~cm}^{-1}$ in the $\mathrm{Cu}(\mathrm{II})$ spectrum, suggesting the symmetry of $\mathrm{D}_{3 \mathrm{~h}}$ for the five coordination $\mathrm{Cu}$ (II) complexes (Slade et al., 1968). The observed absorption at $790 \mathrm{~nm}$ was assigned to the allowed transition state ${ }^{2} \mathrm{~A}_{1} \rightarrow{ }^{2} \mathrm{E}$ (Slade et al., 1968; Sabolová et al., 2011). The complex $\left[\mathrm{Ni}(\mathrm{SCZ})_{2}\right] \mathrm{Cl}_{2}$ showed an octahedral structure, indicated by the magnetic moment of 2.63 BM. Furthermore, two bands at 673 and 755 $\mathrm{nm}$ were assigned to the transition states ${ }^{3} \mathrm{~T}_{1} \rightarrow{ }^{3} \mathrm{~A}_{2}$ and ${ }^{3} \mathrm{~T}_{1}(\mathrm{~F})$ $\rightarrow{ }^{3} \mathrm{~T}_{1}$ (P) (Ramírez-Delgado et al., 2015), respectively. The spectrum of the cobalt compound has essential transitions bands for the octahedral structure that were from ${ }^{4} \mathrm{~T}_{1 \mathrm{~g}} \rightarrow{ }^{4} \mathrm{~T}_{2 \mathrm{~g}}$ and from ${ }^{4} \mathrm{~A}_{2 \mathrm{~g}} \rightarrow{ }^{4} \mathrm{~T}_{1 \mathrm{~g}}$ located at 605 and $685 \mathrm{~nm}$, respectively. As reported, the octahedral structure of $\mathrm{Fe}$ (II) can be confirmed by the absence of the band around $1100 \mathrm{~nm}$ (Goodwin, 1976; Gütlich et al., 1996), Supplementary
Figure S3. The brown color is due to charge transfer transitions from the metal to the ligand orbitals (Gütlich et al., 1996). Moreover, the magnetic moment for Fe(II) confirmed the low spin $\mathrm{d}^{6}$ configuration (0.952 BM). The nephelauxetic parameters such as the interelectronic repulsion parameter (B), covalency factor $(\beta)$, and ligandfield splitting energy $(10 \mathrm{Dq})$ are listed in Table 2 , calculated by the following equations (James E. House, 2013; König, 1971) for $\mathrm{Co}(\mathrm{II})$ :

$$
\begin{aligned}
\mathrm{Dq} & =\left[(85 \mathrm{~V} 32-4(\mathrm{~V} 3-2 \mathrm{~V} 2) 2)^{\S}-9(\mathrm{~V} 3-2 \mathrm{~V} 2)\right] / 340, \\
\mathrm{~B} & =(\mathrm{V} 3-2 \mathrm{~V} 2+30 \mathrm{Dq}) / 15, \\
\beta & =\mathrm{B} / \mathrm{B} 0(\mathrm{~B} 0=971),
\end{aligned}
$$

while for $\mathrm{Ni}(\mathrm{II})$,

$$
\begin{aligned}
\mathrm{Dq} & =\left[(9 \mathrm{~V} 2+\mathrm{V} 3)-(85(\mathrm{~V} 2-\mathrm{V} 3) 2-4(\mathrm{~V} 2+\mathrm{V} 3) 2)^{\S}\right] / 340, \\
\mathrm{~B} & =(\mathrm{V} 2+\mathrm{V} 3-30 \mathrm{Dq}) / 15, \\
\beta & =\mathrm{B} / \mathrm{B} 0(\mathrm{~B} 0=1030) .
\end{aligned}
$$

\section{Thermal Gravimetric Analysis and Kinetic Thermodynamics}

The isolated solid metal complexes were analyzed by TGA to characterize the thermal stability within the temperature range of $25-800^{\circ} \mathrm{C}$. The decomposed stages and their assignments are listed in Table 3 . Figure 3 shows the TG curve for the metal complexes. The $\mathrm{Cu}(\mathrm{II})$ complex presented two stages starting from $150^{\circ} \mathrm{C}$ with the loss of two water molecules, losing weight of $4.5 \%$. The second step was at $205-240^{\circ} \mathrm{C}$ with the loss of all the organic molecules $(75.3 \%)$ and leaving $\mathrm{CuO}$ as a final metallic residue. In addition, $\mathrm{Co}(\mathrm{II})$ and $\mathrm{Ni}$ (II) had the same number of water molecules in the first stage in the range $100-170^{\circ} \mathrm{C}$, followed by decomposing at $250^{\circ} \mathrm{C}$ for anhydrase $\left[\mathrm{Co}(\mathrm{SCZ})_{2} \mathrm{ClOH}_{2}\right] \mathrm{Cl}$ and $230^{\circ} \mathrm{C}$ for $\left[\mathrm{Ni}(\mathrm{SCZ})_{2} \mathrm{Cl}_{2}\right]$ leaving a metallic residue percentage of $17.4 \%$ and $23.2 \%$, respectively. On the contrary, $\left[\mathrm{Fe}(\mathrm{SCZ})_{2} \mathrm{Cl}_{2}\right] .3 \mathrm{H}_{2} \mathrm{O}$ had four steps, which were assigned to slow degradation beginning with evaporating three outside lattice water molecules. The second step had the highest weight loss $(22.5 \%)$ of the complex at $160-170^{\circ} \mathrm{C}$. The last two steps were similar by losing sulfonamide and coupling amine groups at each step until $230^{\circ} \mathrm{C}$ to complete decomposition. The one-step $\mathrm{Zn}$ (II) complex was thermally stable until $200^{\circ} \mathrm{C}$ and began a full fragmentation that was finished at $260^{\circ} \mathrm{C}$. The final resultant residues were metal oxides and counted carbon atoms. 
TABLE 3 | Thermogravimetric data of the five metal complexes.

\begin{tabular}{|c|c|c|c|c|c|c|}
\hline Complex & Step & Temp. range & $\begin{array}{l}\text { Weight loss } \\
\% \text { found } \\
\text { (calc.) }\end{array}$ & Assignments & $\begin{array}{c}\text { Total mass } \\
\text { loss/\% found } \\
\text { (calc.) }\end{array}$ & $\begin{array}{l}\text { Final solid } \\
\text { state residue } \\
\text { found (calc.) }\end{array}$ \\
\hline \multirow[t]{2}{*}[\mathrm{Cu}(\mathrm{SCZ})_{2}\mathrm{Cl}]{$\mathrm{Cl} \cdot 2 \mathrm{H}_{2} \mathrm{O}$} & 1 st & $150-160$ & $4.5(5)$ & $2 \mathrm{H}_{2} \mathrm{O}$ & $79.8(79.9)$ & CuO 11.3 (11.3) \\
\hline & 2nd & $205-240$ & $75.3(74.7)$ & $2 \mathrm{HCl}+2 \mathrm{SO}_{2}+4 \mathrm{~N}_{2}+7 \mathrm{C}_{2} \mathrm{H}_{4}$ & & \\
\hline \multirow[t]{2}{*}[\mathrm{Co}(\mathrm{SCZ})_{2}\mathrm{ClOH}_{2}]{$\mathrm{Cl} .2 \mathrm{H}_{2} \mathrm{O}$} & $1 s t$ & $164-172$ & $10.1(10.5)$ & $2 \mathrm{H}_{2} \mathrm{O}+\mathrm{C}_{2} \mathrm{H}_{2}+2 \mathrm{NH}_{3}$ & $75.3(76.1)$ & $\mathrm{CoO}+10 \mathrm{C} 17.4$ (18.5) \\
\hline & 2nd & $215-246$ & $65.2(65.6)$ & $2 \mathrm{HCl}+2 \mathrm{SO}_{2}+3 \mathrm{~N}_{2}+4 \mathrm{C}_{2} \mathrm{H}_{2}$ & & \\
\hline$\left[\mathrm{Zn}(\mathrm{SCZ})_{2}\right] \mathrm{Cl}_{2}$ & One step & $217-260$ & $72.7(71.9)$ & $2 \mathrm{HCl}+2 \mathrm{HSO}_{2}+4 \mathrm{~N}_{2}+4 \mathrm{C}_{2} \mathrm{H}_{4}$ & $72.7(71.9)$ & ZnO+7C 20.7 (20.1) \\
\hline \multirow[t]{4}{*}[\mathrm{Fe}(\mathrm{SCZ})_{2}\mathrm{Cl}_{2}]{$\cdot 3 \mathrm{H}_{2} \mathrm{O}$} & 1st & $115-131$ & $8.9(7.8)$ & $3 \mathrm{H}_{2} \mathrm{O}$ & $59.39(58.9)$ & $\mathrm{Fe}_{2} \mathrm{O}_{3}+8 \mathrm{C} 26.49$ (27.83) \\
\hline & 2nd & $157-177$ & $22.5(23)$ & $2 \mathrm{CN}+5 \mathrm{C}_{2} \mathrm{H}_{2}$ & & \\
\hline & $3 r d$ & $302.33-340$ & $13.4(13.1)$ & $2 \mathrm{~N}_{2}+\mathrm{SO}_{2}$ & & \\
\hline & 4th & 625-660 & $14.59(15)$ & $2 \mathrm{~N}_{2}+\mathrm{SO}_{2}$ & & \\
\hline \multirow[t]{2}{*}[\mathrm{Ni}(\mathrm{SCZ})_{2}\mathrm{Cl}_{2}]{$\cdot 2 \mathrm{H}_{2} \mathrm{O}$} & 1st & 80-94 & $10.8(10.5)$ & $2 \mathrm{H}_{2} \mathrm{O}+2 \mathrm{C}_{2} \mathrm{H}_{2}$ & $73.7(74.4)$ & $\mathrm{NiO}+8 \mathrm{C} 23.2(23.5)$ \\
\hline & 2nd & 199-234 & $62.9(63.9)$ & $2 \mathrm{HCl}+2 \mathrm{SO}_{2}+4 \mathrm{~N}_{2}+4 \mathrm{C}_{2} \mathrm{H}_{2}$ & & \\
\hline
\end{tabular}

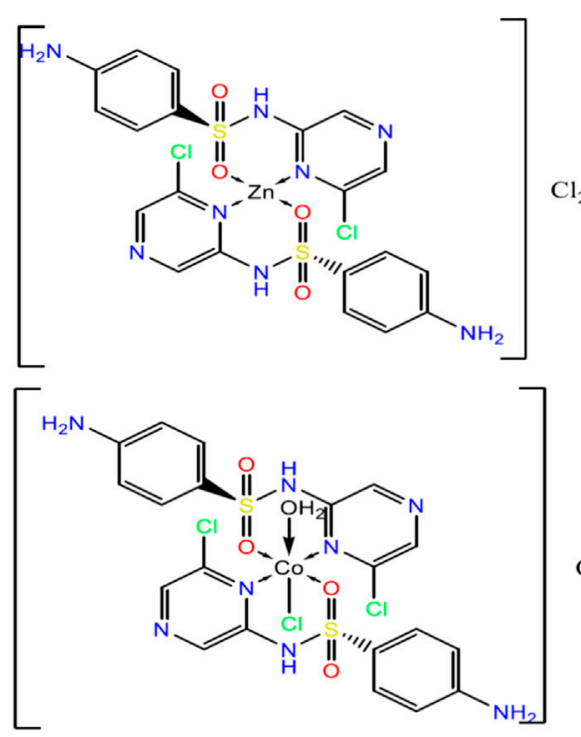

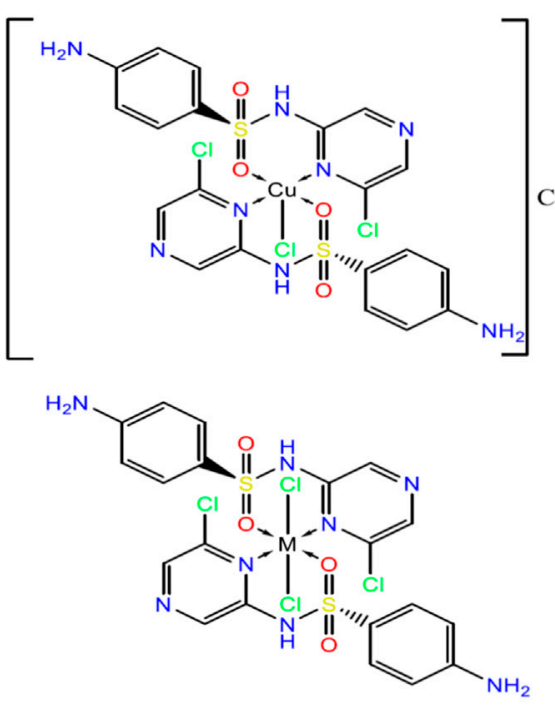

$\mathrm{M}=\mathrm{Ni}(\mathrm{II}), \mathrm{Fe}(\mathrm{II})$

FIGURE 4 | The suggested structures of the SCZ metal complexes.

Thermodynamic data, activation energy (Ea, $\mathrm{kJmol}^{-1}$ ), and Arrhenius factor $\left(\mathrm{A}, \mathrm{S}^{-1}\right)$ for the metal complexes were obtained by plotting the relationship of the Coats-Redfern (CR) equation (Coats and Redfern, 1964) or Horowitz-Metzger (HM) equation (Horowitz and Metzger, 1963), as recorded in Supplementary Table S2. The following equations were employed to calculate enthalpy activation $\Delta \mathrm{H}=\mathrm{Ea}-\mathrm{RT}$, activation entropy $\Delta S=\mathrm{R}[\operatorname{In}(\mathrm{Ah} / \mathrm{kT})]$, and Gibbs free energy $\Delta \mathrm{G}=\Delta \mathrm{H}-\mathrm{T} \Delta \mathrm{S}$ for each decomposition step. From the results in Supplementary Table S3, it can be seen that the activation energy $E_{a}$ values were high and varied between $10^{5}$ and $10^{4} \mathrm{~kJ}$ $\mathrm{mol}^{-1}$, which translate to good stability for SCZ metal complexes. Moreover, the negative entropy values indicated the activated metal complexes need a higher-order system than the reactants. Enthalpy results support the endothermic DTG curve reactions $(\Delta \mathrm{H}>0)$.

\section{Structural Interpretation}

From the above observations, the suggested coordination mode of the SCZ drug toward M(II) metal ions conformed with the structure and formulas designed as shown in Figure 4. The coordination sites with $\mathrm{SO}_{2}$ and/or pyrazine were reported in the literature (Khedr and Saad, 2015; Radha et al., 2016; Abdel-Kader et al., 2019). Moreover, the Cu(II) complex has a trigonal bipyramidal structure containing the bidentate ligand and one $\mathrm{Cl}$ ion. The octahedral arrangements were observed in three metal ions, $\mathrm{Ni}(\mathrm{II}), \mathrm{Fe}(\mathrm{II})$, and $\mathrm{Co}(\mathrm{II})$, binding to $\mathrm{Cl}$ ions, compatible with the conductance results. The $\mathrm{Zn}$ (II) complex showed a tetrahedral geometry, which is one of the passable possible structures for an ion metal (Dudev and Lim, 2000; Jana et al., 2017). There were many attempts to get single crystals from the metal complexes using the diffusion method with DMS and chloroform or ethanol and benzene but all 

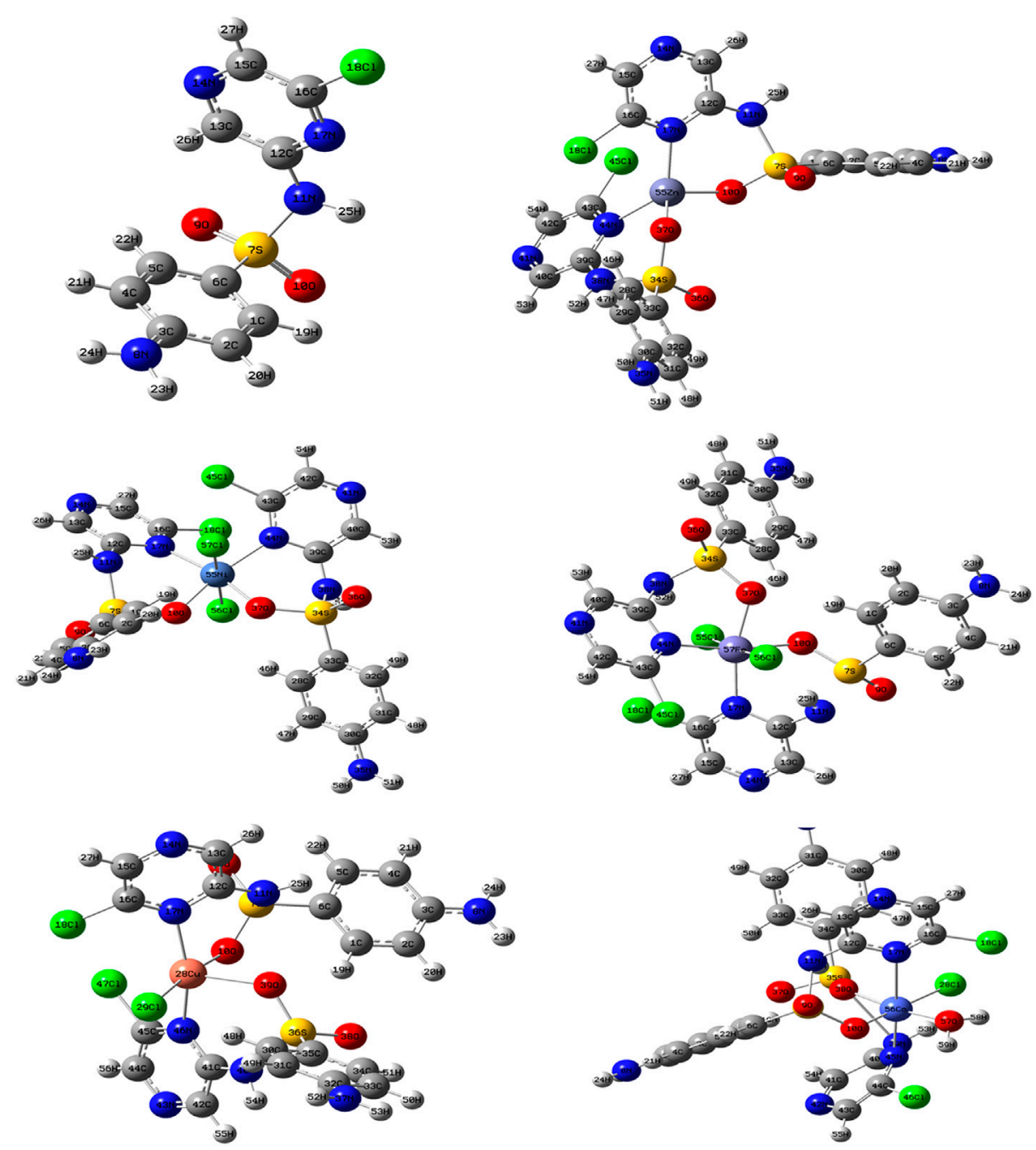

FIGURE 5 | The optimized geometry with the numbering system of the free SCZ ligand and the five metal complexes.

failed. Therefore, a theoretical calculation was carried out to verify the structural and biological features.

\section{Molecular Orbital Calculations Geometry of the Ligand and Metal Complex}

The comparison between the optimized geometry parameters such as the bond length and the angles of the free ligand and the complexes, $\mathrm{Cu}-\mathrm{SCZ}, \mathrm{Co}-\mathrm{SCZ}, \mathrm{Ni}-\mathrm{SCZ}, \mathrm{Zn}-\mathrm{SCZ}$, and $\mathrm{Fe}-\mathrm{SCZ}$, is illustrated in Supplementary Table S4. The optimized geometry and numbering system of all studied metal complexes are presented in Figure 5. In general, the bond lengths around the metal ion in the complexes are longer than those of the free ligand due to the influence of the coordination process. In the Co-SCZ complex, the coordination sphere was completed with one $\mathrm{Cl}$ ion and one water molecule forming an octahedral arrangement. In contrast, $\mathrm{Ni}(\mathrm{II})$ and $\mathrm{Fe}(\mathrm{II})$ bonded to two $\mathrm{Cl}$ ions. The bond lengths of the $\mathrm{Ni}(\mathrm{II}), \mathrm{Co}(\mathrm{II})$, and $\mathrm{Fe}(\mathrm{II})$ ions with the donating sites of the ligand (Supplementary Table S4) suggest a minor distorted octahedral geometry around the central metal (ElSonbati et al., 2016; Abdel-Kader et al., 2019). The new bond length of $\mathrm{M}-\mathrm{N}$ and $\mathrm{M}-\mathrm{O}$ bonds showed varied elongation upon complexation. Those bonds were in the range 1.94-2.4 $\AA$, which indicates small ionic properties of the covalent bonds (Abdel-Kader et al., 2019). For the trigonal bipyramid, $\mathrm{Cu}$ (II) complex, the angles of O10-M-N17 and O38-M-Cl28 were 92.6 and $91.9 \underline{o}$, respectively, which showed a small deviation from the regular penta-coordination geometry angle between the two nearest neighbor atoms (Gillespie, 1961). The average of the angles of the $\mathrm{Zn}(\mathrm{II})$ complex is $112.3 \mathrm{o}$, indicating that this complex adopts a square planar with distortion by $0.03^{\circ}$.

\section{The Frontier Molecular Orbital and Reactivity Properties}

Frontier molecular orbital, FMO, studies provide the electronic characteristics of molecular systems and the reactivity of the compounds (Abdel-Kader et al., 2019; Sharfalddina et al., 2020a). Thus, the map of HOMO and LUMO energies of the studied 

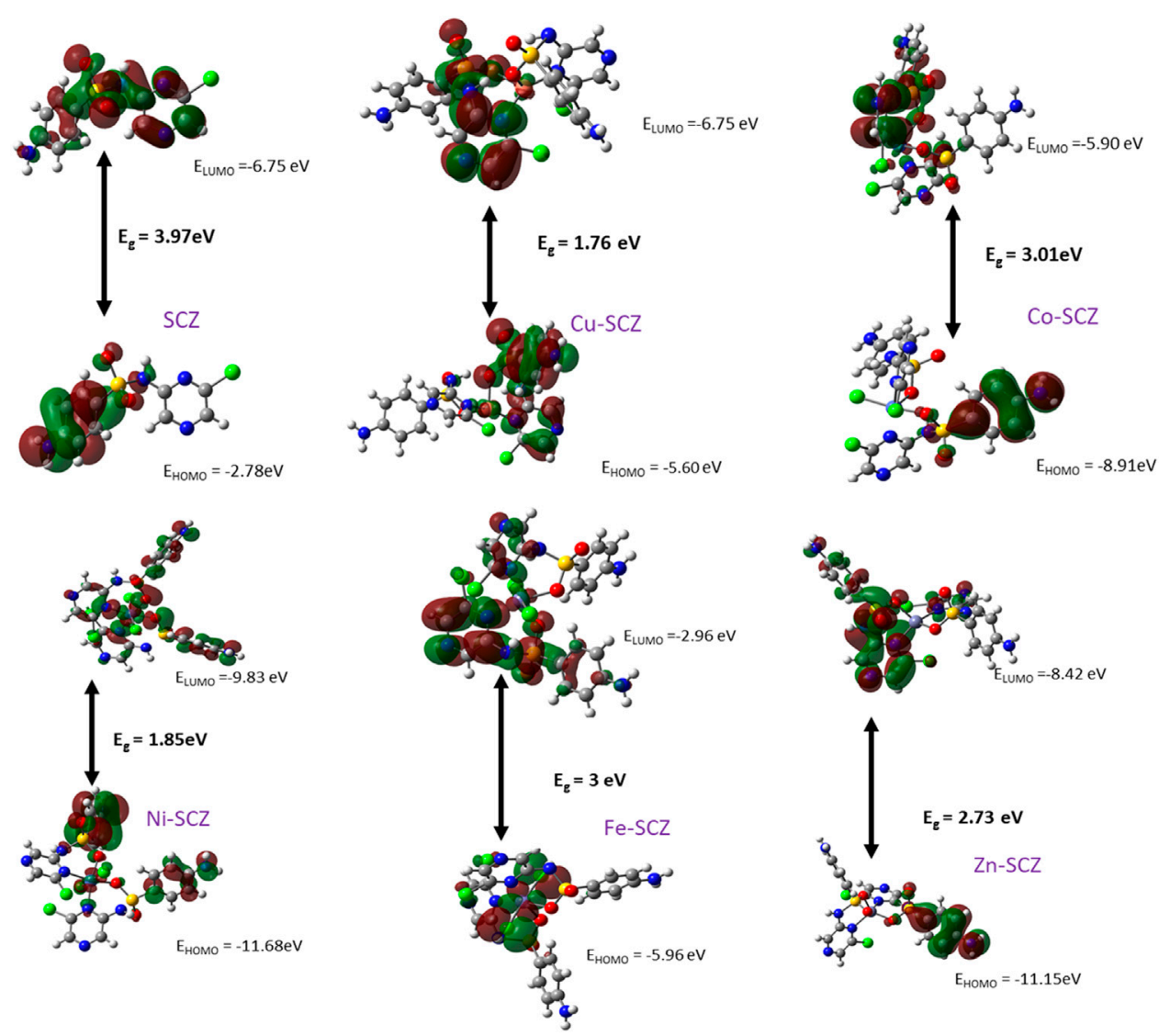

FIGURE 6 | HOMO and LUMO plots of the SCZ and the metal complexes using DFT/B3LYP.

ligand and its complexes in the ground state was extracted and is presented in Figure 6. Moreover, the calculation of the gap energy $\left(\mathrm{E}_{\mathrm{g}}\right)$ with the difference between the $\mathrm{E}_{\mathrm{HOMO}}$ and the $\mathrm{E}_{\mathrm{LUMO}}$ gives a good indicator of the molecular stability and can be used to describe the compound hardness or softness. Large $\mathrm{E}_{\mathrm{g}}$ values indicate a hard molecule and low reactivity, while soft molecules have a small $\mathrm{E}_{\mathrm{g}}$ value and more polarizable ability. The $\mathrm{E}_{\mathrm{HOMO}}$ for the free SCZ was $-3.97 \mathrm{eV}$ and located on the sulfonylaniline moiety, and the $\mathrm{E}_{\mathrm{LUMO}}=-6.75 \mathrm{eV}$ was distributed over the molecule. Supplementary Table $S 5$ presents the $E_{\mathrm{g}}$ and the global reactivity descriptors. The $\mathrm{Cu}$ (II) complex had practical reactivity among the synthesized metal complexes. Ni(II) followed this compound with low $\mathrm{E}_{\mathrm{g}}=1.85 \mathrm{eV}$. The chemical hardness values showed that $\mathrm{Co}$ (II) and $\mathrm{Fe}(\mathrm{II})$ are the most stable complexes with less reactivity. In contrast, $\mathrm{Cu}$ (II) and $\mathrm{Ni}$ (II) had the lowest values reflecting the softness and the inhibition ability of the molecules. The negative values of the chemical potential of all complexes indicated that all coordination processes are spontaneous (Rahmouni et al., 2019).

\section{Biological Studies}

\section{DNA Binding Study and Cleavage Experiments}

Drugs work largely by binding to a biological target such as DNA or specific protein and modifying its structure or inhibiting its activity. DNA in the biomolecules represents a major target in the development strategies of the drugs designed. Thus, a spectroscopic technique was used to study the binding ability of the free ligand and the five metal complexes simultaneously with varying concentrations of CT-DNA. In Supplementary Table S6, the maxima absorption band for the fixed concentration solution in DMSO/buffer and the binding parameter for SCZ and metal compounds are presented. Although all compounds had a blue shift, the SCZ ligand was hyperchromic in the molar absorptivity, while the SCZ metal complexes had a hypochromic effect (Figure 7A,B) due to a strong change in DNA conformation in its structure after interacting with the ligand or the metal complex (Sirajuddin et al., 2013). The hyperchromic effect is a result of DNA helix denaturation due to the resulting binding to the compound. This resulted in a limitation of the hydrogen bond between the complementary bases in the DNA double helix and the formation of a single-stranded DNA. The presence of numerous bases in free form in the solution increased the absorbance of the single-stranded DNA (Sirajuddin et al., 2013; Alsaeedi et al., 2020). Hypochromic type is due to the strong damage of the double-helical structure (Sirajuddin et al., 2012), which leads the $\pi^{*}$ orbital of the ligand in the synthesized metal complexes to couple with the $\pi$ orbitals in the DNA base 

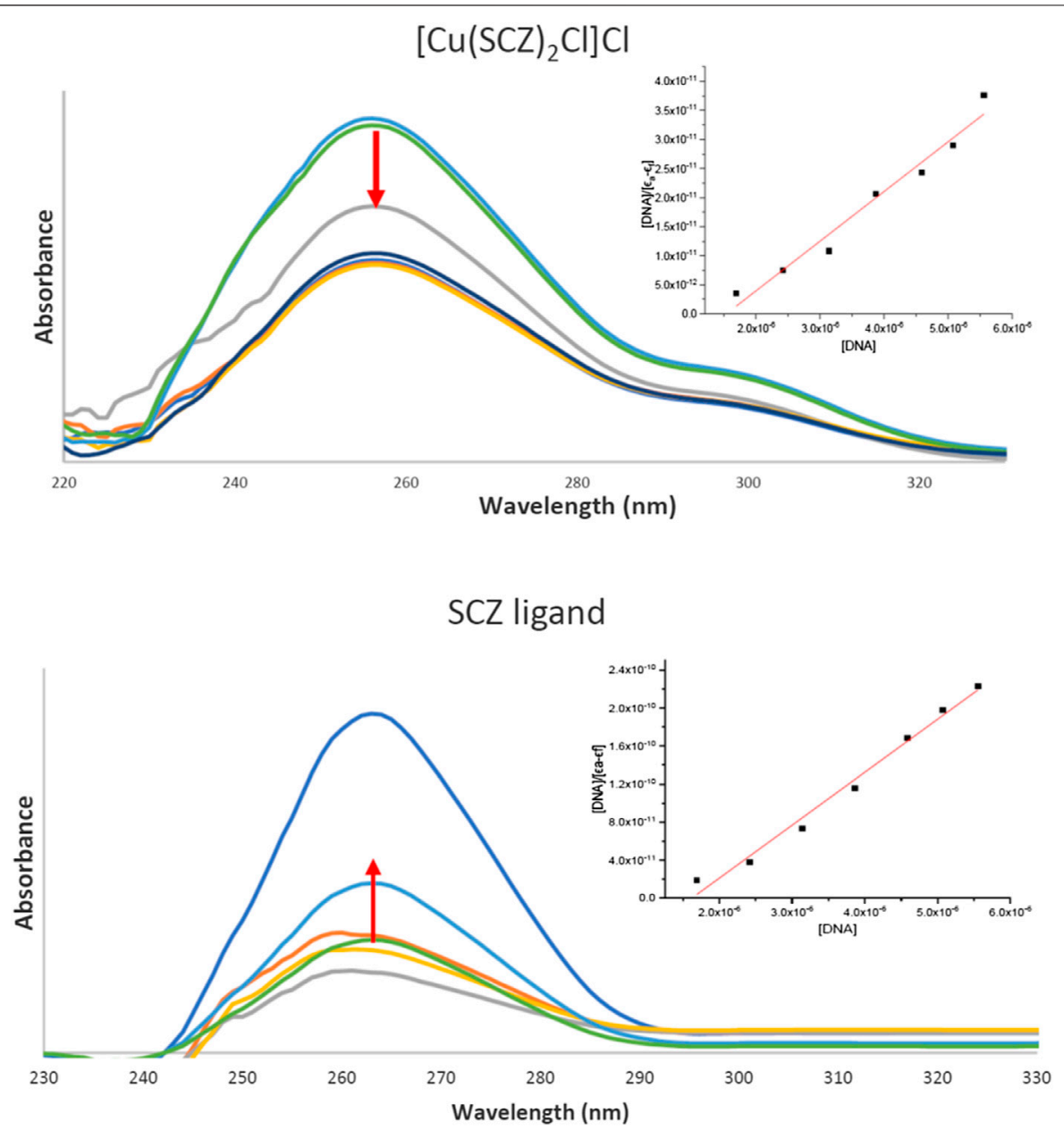

FIGURE 7 |UV absorption spectra of the $\left[\mathrm{Cu}(\mathrm{SCZ})_{2} \mathrm{Cl}_{2}\right]$ complex (A) and the ligand $\mathrm{SCZ}$ (B) in a buffer upon the addition of CT-DNA. Plots of [DNA] vs. [DNA]/ $\epsilon_{-}-\epsilon_{f}$ for the titration of CT-DNA.

pairs after binding. The resulting coupled $\pi^{*}$ will be partially filled, thus decreasing the possibility of electron transition, causing hypochromicity (Ju et al., 2011; Sirajuddin et al., 2012).

The binding constant, $\mathrm{K}_{\mathrm{b}}$, was between the value of the DNA minor groove binding $\mathrm{Ru}(\mathrm{II})$ complexes and classical intercalator $\left(10^{4}-10^{7} \mathrm{M}^{-1}\right)$ (Vahdati et al., 2014), thus indicating an intercalation interaction mode with the DNA biomolecule. The $\mathrm{K}_{\mathrm{b}}$ value of the $\mathrm{Cu}(\mathrm{II})$ complex was higher than that of the free ligand and the other complexes, which suggested a good impact and proved the role of the cation $\mathrm{Cu}$ (II) in the binding process (Al-Amiery et al., 2012; Emwas et al., 2013). In sum, metal complexes could be ordered according to the decreasing $\mathrm{Ka}$ value: $\mathrm{Cu}(\mathrm{II})>\mathrm{Ni}(\mathrm{II})=$ $\mathrm{Fe}(\mathrm{II})>\mathrm{Zn}(\mathrm{II})>\mathrm{Co}(\mathrm{II})$. Moreover, the negative value of $\Delta G$ showed the spontaneous interaction of the compound with DNA, Supplementary Table S6.

\section{Molecular Docking}

Molecular docking is a theoretical calculation approach in drug design and discovery that can also be used to help scientists propose a drug interaction model and to understand the behavior of the new drug toward a biological target (Gupta et al., 2018; Márquez et al., 2020). Moreover, this method can be used to predict the binding affinity between a selected biological target and drug compounds. We performed a molecular docking study of the five metal complexes first with DNA. This revealed a strong DNA binding constant for only the $\mathrm{Cu}$ (II) compound. Thus, docking with a DNA helix was conducted to obtain more details of this interaction. Figure 8 shows that the $\mathrm{Cu}-\mathrm{SCZ}$ complex fits well between base pairs of B-DNA, forming intercalation interactions using hydrogen bonds with amino bases leading to uncoiling of the base pairs. It has been reported that this stacking model leads to inhibition of DNA replication in rapidly growing cancer cells (Shahabadi et al., 2017).

We also performed molecular docking of the free ligand and the five metal complexes with colon and breast cancer-related proteins. For colon cancer, we selected TNIK $(\mathrm{PDB}=2 \mathrm{X} 7 \mathrm{~F})$ and topoisomerase II enzyme $(\mathrm{PDB}=4 \mathrm{~F} 9 \mathrm{M})$, which are candidate therapeutic targets for colorectal cancer (Sapna 


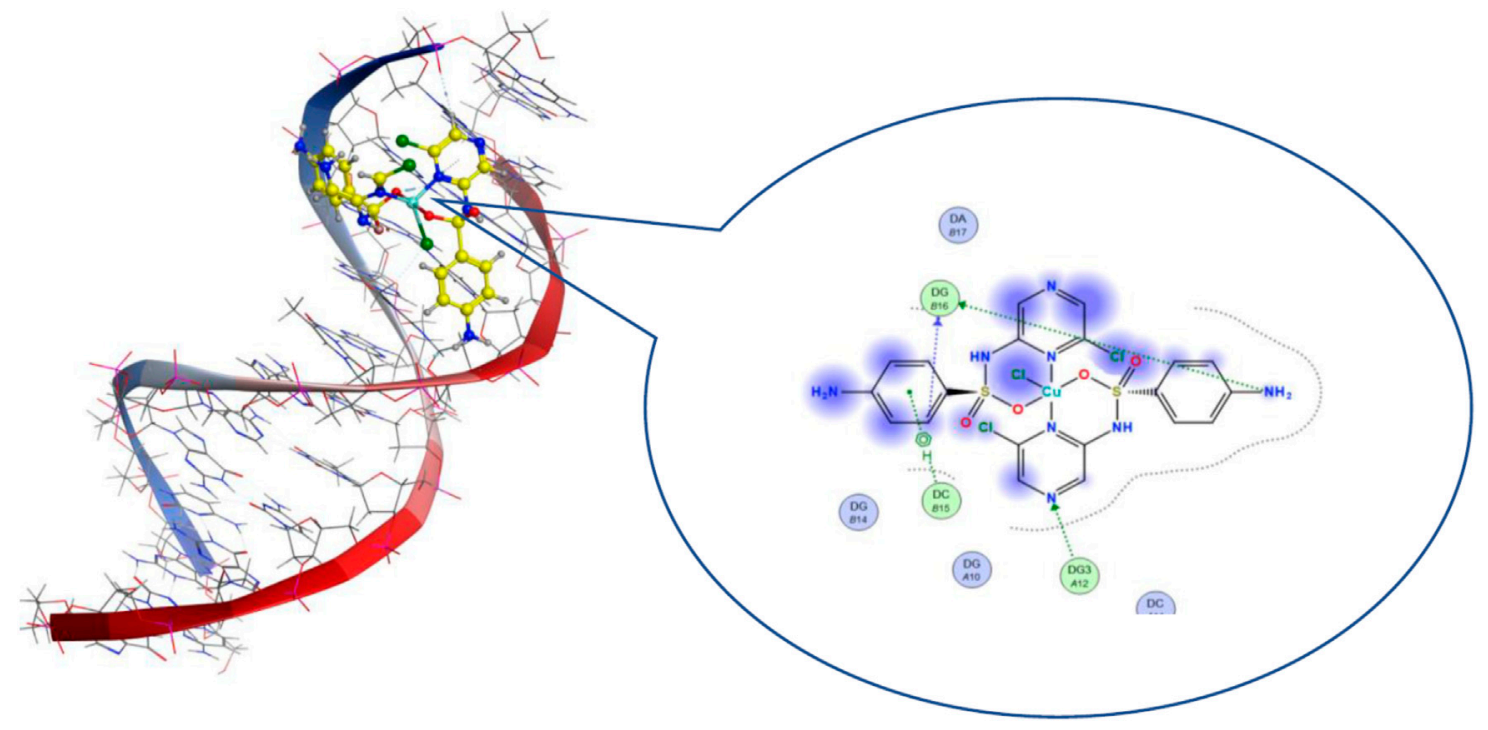

FIGURE $8 \mid 3 D$ and 2D views of interactions of 8 with B-DNA.

Rani and Kumar, 2014; Lee et al., 2017; Rosita and Begum, 2020). Moreover, the breast cancer-associated estrogen receptor (ID: 3ERT) and Hsp90 protein receptor (ID: $1 \mathrm{H} 7 \mathrm{~K})$ were chosen based on previous research suggesting their value as targets for potential breast cancer therapy (Zagouri et al., 2013; Acharya et al., 2019). Table 4 presents the binding scores for the ligand and metal complexes against the selected proteins. The strongly negative values of free binding energy (S) suggest a good binding to both proteins. Generally, $\mathrm{Cu}-\mathrm{SCZ}$ showed a stronger interaction pattern toward the investigated proteins than the free SCZ ligand and the other complexes. Comparing the interaction of the free ligand to the colon cancer-associated protein $2 \mathrm{X} 7 \mathrm{~F}$ with that of the $\mathrm{Cu}(\mathrm{II})$ compound, the interaction for the SCZ molecule was established by donating a hydrogen atom to the oxygen atom in glutamic acid and accepting an $\mathrm{H}$ bond from cysteine to one of the sulfonyl oxygen atoms. Moreover, the chloropyrazine ring interacted with both valine 39 and valine 170 to increase the free energy binding. Although the $\mathrm{Cu}$ (II) complex had the same binding constant with the investigated protein as the free ligand, the former had two ionic interactions with the glutamic residue with the binding energy of $-6.5 \mathrm{kcal} \mathrm{mol}^{-1}$ that could enhance the interaction. In contrast, the breast cancer-associated protein receptor 3ERT displayed different binding characteristics with the free ligand and the $\mathrm{Cu}(\mathrm{II})$ complex. The amino group $\left(\mathrm{NH}_{2}\right)$ in the SCZ molecule formed a hydrogen bond by donating this hydrogen to the glutamic and leucine oxygen atoms. The presence of two amino groups in the $\mathrm{Cu}$ (II) molecules elevated the interaction energies to $4.5 \mathrm{kcal} \mathrm{mol}^{-1}$ which bonded to methionine 538, methionine 343, and cysteine. Additionally, it formed an ionic interaction with the asparagine amino residue, which stabilizes this interaction more than the SCZ ligand. The different interaction models of the SCZ ligand and $\mathrm{Cu}$ (II) complex are presented in Table 5 .

The surface maps were built over the dummy atoms as receptors to provide a better view of the molecular surface that was expressed in purple color for H-bonding, green for hydrophobic sites, and blue for polarity. The ligand and metal complex exhibited high occupancy inside the groove surface for both investigated proteins. Thus, good inhibitory activity is predicted for those compounds.

\section{Cytotoxicity Results}

There are several human cancer cell lines derived from different cancer types that have been commonly used to evaluate the anticancer properties of potential drugs. Among those types,

\begin{tabular}{|c|c|c|c|c|c|c|c|}
\hline Protein/complex & & SCZ & $\mathrm{Cu}-\mathrm{SCZ}$ & Co-SCZ & $\mathrm{Ni}-\mathrm{SCZ}$ & $\mathrm{Fe}-\mathrm{SCZ}$ & Zn-SCZ \\
\hline \multirow[t]{2}{*}{ Colon cancer protein } & $2 X 7 F$ & -5.67657 & -6.67613 & -6.39108 & -5.68732 & -6.39108 & -6.36569 \\
\hline & 4F9M & -6.55138 & -7.24939 & -6.71789 & -6.88243 & -6.80609 & -7.2411 \\
\hline \multirow[t]{2}{*}{ Breast cancer protein } & 3ERT & -6.02021 & -6.5352 & -6.18126 & -6.0157 & -6.24734 & -6.01604 \\
\hline & $1 \mathrm{H} 7 \mathrm{~K}$ & -5.49007 & -7.73247 & -6.22617 & -6.80484 & -6.55553 & -7.10101 \\
\hline
\end{tabular}


TABLE 5 | 2D and 3D molecular docking mode and interaction between SCZ and the Cu(II) complex with the colon protein receptor (2X7F) and the breast protein receptor (3ERT).

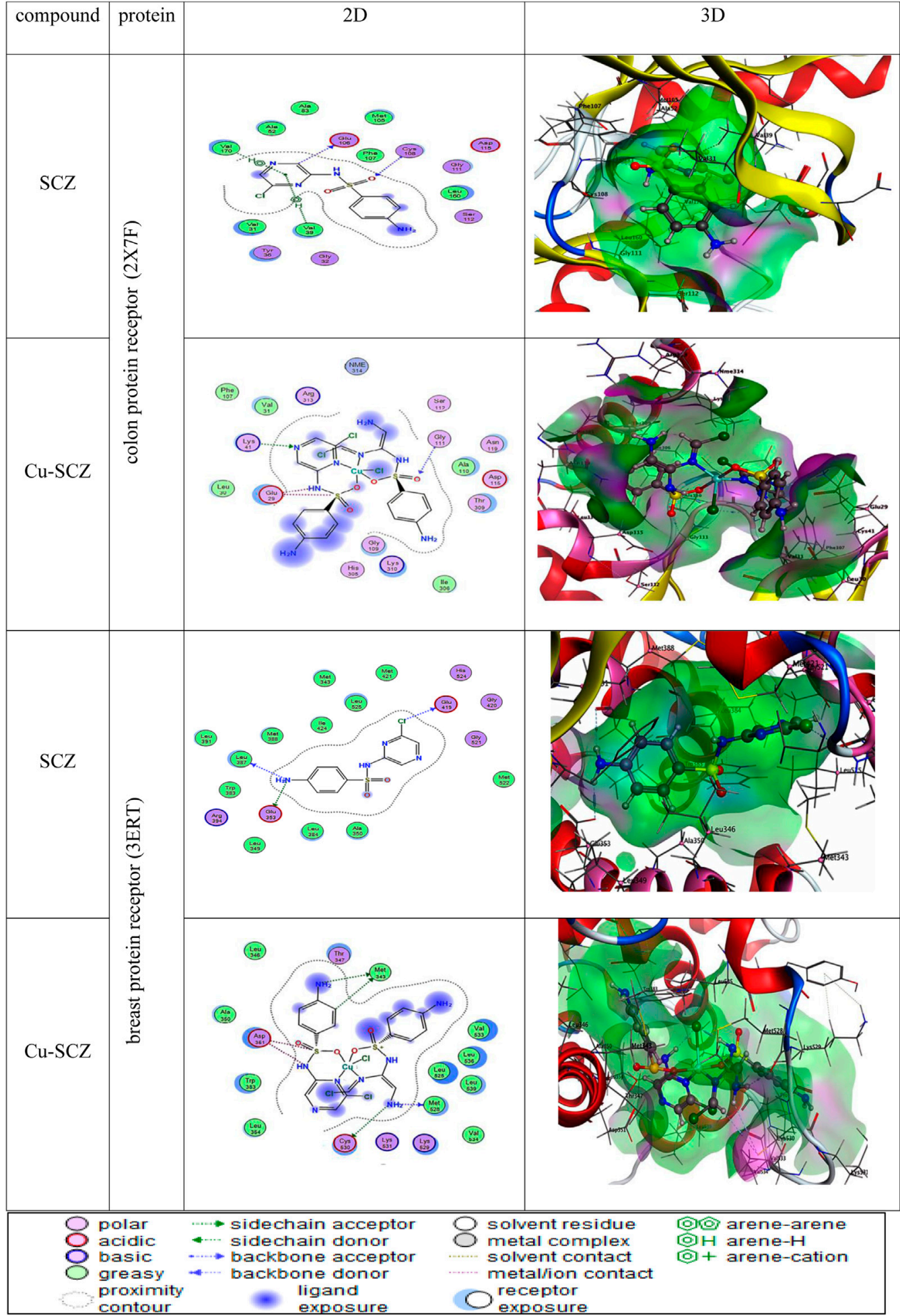


TABLE 6 | Cytotoxic activity of SCZ and its metal complexes against human tumor cells and SD values.

\begin{tabular}{lcccc}
\hline \multirow{2}{*}{ Compound } & \multicolumn{4}{c}{ In vitro cytotoxicity $\mathbf{I C}_{\mathbf{5 0}}(\boldsymbol{\mu} \mathbf{g} / \mathbf{m l} \mathbf{)} \mathbf{1} / \mathbf{S D}$} \\
\cline { 2 - 5 } & $\begin{array}{c}\text { Breast } \\
\text { cell line (MCF-7) }\end{array}$ & SD & $\begin{array}{c}\text { Colon } \\
\text { cell line (CaCo-2) }\end{array}$ & SD \\
\hline $\mathrm{SCZ}$ ligand & 215.24 & \pm 0.67 & 97.6 & \pm 0.45 \\
{$\left[\mathrm{Cu}(\mathrm{SCZ})_{2} \mathrm{Cl}\right] \mathrm{Cl}$} & 86.2 & \pm 0.64 & 23.84 & \pm 0.33 \\
{$\left[\mathrm{Zn}(\mathrm{SCZ})_{2} \mathrm{Cl}_{2}\right.$} & 111.91 & \pm 0.36 & 198.44 & \pm 0.25 \\
{$\left[\mathrm{Ni}(\mathrm{SCZ})_{2} \mathrm{Cl}_{2}\right]$} & 45.62 & \pm 0.28 & 106.87 & \pm 0.34 \\
{$\left[\mathrm{Co}(\mathrm{SCZ})_{2} \mathrm{ClOH}_{2}\right] \mathrm{Cl}$} & 54.23 & \pm 0.52 & 190.1 & \pm 0.30 \\
{$\left[\mathrm{Fe}(\mathrm{SCZ})_{2} \mathrm{Cl}_{2}\right]$} & 284.25 & \pm 0.31 & 362.9 & \pm 0.41
\end{tabular}

${ }^{1} / \mathrm{C}_{50}(\mathrm{mg} / \mathrm{ml}): 1-10$ (very strong), 11-20 (strong), 21-50 (moderate), 51-100 (weak), and above 100 (non-cytotoxic).

we selected the breast cancer cell line (MCF-7), which is a good candidate particularly for estrogen receptor (ER)-positive breast cancer cell experiments (Sweeney et al., 2012; Comşa et al., 2015), and $\mathrm{CaCo}-2$, which expresses normal enterocytic phenotypes (Hirata et al., 1993).

In vitro cytotoxicity of SCZ and the metal complexes was examined with the two cancer cell lines, human breast cancer (MCF-7) and human colon cancer (CaCo-2). The obtained results for the free drug and metal complexes are listed in Table 6 as the inhibitory concentration $\left(\mathrm{IC}_{50}\right)$ for each cell line and SD values. Initially, the results matched the docking prediction, revealing that the $\mathrm{Cu}-\mathrm{SCZ}$ complex has the highest activity against the human colon cancer cell line (CaCo-2) with $\mathrm{IC}_{50}=23.84 \mu \mathrm{g} / \mathrm{ml}$. This is more effective than that reported for $\mathrm{Ru}(\mathrm{III})$ complexes of sulfadimidine against colon cell lines (Refat et al., 2016). There are some features of copper complexes that can contribute to them forming more functional metal drugs for cancer treatments (Martin et al., 2018). For example, the associated compounds can modulate the properties of the metal ions and enhance solubility in extracellular fluids (Jungwirth et al., 2011). Moreover, they can also balance their lipophilic-hydrophilic properties to traverse the two layers' lipid membrane (Santini et al., 2013).

In the breast cell line (MCF-7), the $\mathrm{Ni}$ (II) complex could also inhibit the growth of breast cancer lines (MCF-7) from $45.62 \mu \mathrm{g} /$ $\mathrm{ml}$ to $50 \%$. This effectiveness likely derives from the practical roles of nickel ions in cellular functions and their abundance in the human body (Deo et al., 2016).

Other tested compounds showed varied results, and those with values between 51 and $100 \mu \mathrm{g} / \mathrm{ml}$ were weakly cytotoxic, while those above $100 \mu \mathrm{g} / \mathrm{ml}$ were non-cytotoxic.

\section{CONCLUSION}

The new metal-based drugs, $\mathrm{Cu}(\mathrm{II}), \mathrm{Co}(\mathrm{II}), \mathrm{Zn}(\mathrm{II}), \mathrm{Ni}(\mathrm{II})$, and $\mathrm{Fe}(\mathrm{II})$, of sulfaclozine complexes were synthesized, and their structures were affirmed by various analytical approaches. The molar ratio method indicated that the ratio of the metal to the ligand was 1:2. Moreover, spectroscopic data from IR spectroscopy showed that SCZ is a bidentate ligand coordinated by one oxygen atom of the $\mathrm{SO}_{2}$ group and the pyrazine nitrogen atom. Moreover, the absorption results revealed that the $\mathrm{Fe}(\mathrm{II}), \mathrm{Co}(\mathrm{II})$, and $\mathrm{Ni}(\mathrm{II})$ metal complexes have an octahedral structure. The solid EPR spectrum showed a trigonal bipyramidal geometry for the $\mathrm{Cu}$ (II) complex. The thermal decomposition assignments agreed with the suggested structure of the obtained complexes. The optimized geometries were match the experimentalsuggested structures. The energy gap, $E_{g}$, values for the complexes were lower than that of the ligand, meaning that the complexes are more reactive. The low computed hardness parameter of $\mathrm{Cu}$ (II) revealed strong bio-reactivity. The DNA $\mathrm{K}_{\mathrm{b}}$ values were presented in descending order, $\mathrm{Cu}$ (II) $>\mathrm{N}$ (II) $=\mathrm{Fe}(\mathrm{II})>\mathrm{Co}(\mathrm{II})>\mathrm{Zn}(\mathrm{II})$, and were greater than the binding constant for the free ligand $\left(6.67 \times 10^{5} \mathrm{M}^{-1}\right)$. The computed free binding energy for the two proteins, breast cancer receptor protein and colon cancer receptor protein, illustrated the lowest negative score for the $\mathrm{Cu}(\mathrm{II})$ and Ni(II) complexes. The experimental cytotoxicity results presented a moderated anticancer strength of the $\mathrm{Cu}-\mathrm{SCZ}$ compound. Finally, we suggest as a future perspective to study the activity of these complexes or other metal complexes by external inducements such as light or oxidizing materials.

\section{DATA AVAILABILITY STATEMENT}

The original contributions presented in the study are included in the article/Supplementary Material, and further inquiries can be directed to the corresponding author.

\section{AUTHOR CONTRIBUTIONS}

AAS synthesized and characterized the metal complexes. MAA supervised the project and wrote the original draft. AE performed EPR analysis. AE and MJ wrote, reviewed, and edited the paper. All authors read and agreed to the published version of the manuscript.

\section{ACKNOWLEDGMENTS}

Computation for the work described in this paper was supported by King Abdulaziz University's High-Performance Computing Center (Aziz Supercomputer) (http://hpc.kau.edu.sa). We thank King Fahad Medical Research Center for the use of their facilities and also thank King Abdullah University of Science and Technology (KAUST) for their support.

\section{SUPPLEMENTARY MATERIAL}

The Supplementary Material for this article can be found online at: https://www.frontiersin.org/articles/10.3389/fchem.2021.644691/ full\#supplementary-material 


\section{REFERENCES}

Abdel-Kader, N. S., Abdel-Latif, S. A., El-Ansary, A. L., and Sayed, A. G. (2019). Combined Experimental, DFT Theoretical Calculations and Biological Activity of Sulfaclozine Azo Dye with 1-Hydroxy-2-Naphthoic Acid and its Complexes with Some Metal Ions. New J. Chem. 43, 17466-17485. doi:10.1039/c9nj04594e

Abdel-Rhman, M. H., Hussien, M. A., Mahmoud, H. M., and Hosny, N. M. (2019). Synthesis, Characterization, Molecular Docking and Cytotoxicity Studies on N-Benzyl-2-Isonicotinoylhydrazine-1-Carbothioamide and its Metal Complexes. J. Mol. Struct. 1196, 417-428. doi:10.1016/j.molstruc.2019.06.092

Acharya, R., Chacko, S., Bose, P., Lapenna, A., and Pattanayak, S. P. (2019). Structure Based Multitargeted Molecular Docking Analysis of Selected Furanocoumarins against Breast Cancer. Sci. Rep. 9, 1-13. doi:10.1038/ s41598-019-52162-0

Ajibade, P. A., Idemudia, O. G., and Okoh, A. I. (2013). Synthesis, Characterization and Antibacterial Studies of Metal Complexes of Sulfadiazine with N-Alkyl-NPhenyldithiocarbamate. Bull. Chem. Soc. Ethiopia 27, 77-84. doi:10.4314/bcse. v27i1.8

Ajibade, P. A., Kolawole, G. A., O’Brien, P., Helliwell, M., and Raftery, J. (2006). Cobalt(II) Complexes of the Antibiotic Sulfadiazine, the X-ray Single crystal Structure of $[\mathrm{Co}(\mathrm{C} 10 \mathrm{H} 9 \mathrm{~N} 4 \mathrm{O} 2 \mathrm{~S}) 2(\mathrm{CH} 3 \mathrm{OH}) 2]$. Inorg. Chim. Acta 359, 3111-3116. doi:10.1016/j.ica.2006.03.030

Al-Amiery, A. A., Kadhum, A. A. H., and Mohamad, A. B. (2012). Antifungal and Antioxidant Activities of Pyrrolidone Thiosemicarbazone Complexes. Bioinorganic Chem. Appl. 2012, 795812. doi:10.1155/2012/795812

Alahmari, F., Davaasuren, B., Emwas, A.-H., M.F.J. Costa, P., and Rothenberger, A. (2019). Tris(ethylenediamine)Nickel(II) Thio-Hydroxogermanate Monohydrate: Synthesis, crystal Structure, 1H NMR, EPR, Optical and Magnetic Properties. Inorg. Chim. Acta 488, 145-151. doi:10.1016/j.ica.2019. 01.019

Alghrably, M., Dudek, D., Emwas, A-H., Jaremko, Ł., Jaremko, M., and RowińskaŻyrek, M.(2019). MCopper (II) and Amylin Analogues: A Complicated Relationship. Inorg. Chem. 59 (4), 2527-2535. doi:10.1021/acs.inorgchem. 9 b03498

Ali, I., Wani, W. A., and Saleem, K. (2013). Empirical Formulae to Molecular Structures of Metal Complexes by Molar Conductance. Synth. Reactivity Inorg. Metal-Organic, Nano-Metal Chem. 43, 1162-1170. doi:10.1080/15533174.2012. 756898

Alley, M. C., Scudiero, D. A., Monks, A., Hursey, M. L., Czerwinski, M. J., Fine, D. L., et al. (1988). Feasibility of Drug Screening with Panels of Human Tumor Cell Lines Using a Microculture Tetrazolium Assay. Cancer Res. 48, 589-601.

Alsaeedi, M. S., Babgi, B. A., Hussien, M. A., Abdellattif, M. H., and Humphrey, M. G. (2020). DNA-binding and Anticancer Activity of Binuclear Gold(I) Alkynyl Complexes with a Phenanthrenyl Bridging Ligand. Molecules 25, 1033. doi:10. 3390/molecules 25051033

Arjmand, F., and Jamsheera, A. (2011). DNA Binding Studies of New Valine Derived Chiral Complexes of Tin(IV) and Zirconium(IV). Spectrochimica Acta A: Mol. Biomol. Spectrosc. 78, 45-51. doi:10.1016/j.saa.2010.06.009

Carr, H. S., Wlodkowski, T. J., and Rosenkranz, H. S. (1973). Silver Sulfadiazine: In Vitro Antibacterial Activity. Antimicrob. Agents Chemother. 4, 585-587. doi:10. 1128/aac.4.5.585

Coats, A. W., and Redfern, J. P. (1964). Kinetic Parameters from Thermogravimetric Data. Nature 201, 68-69. doi:10.1038/201068a0

Comşa, Ş., Cimpean, A. M., and Raica, M. (2015). The story of MCF-7 Breast Cancer Cell Line: 40 Years of Experience in Research. Anticancer Res. 35, 3147-3154.

Davila, Y. A., Sancho, M. I., Almandoz, M. C., and Blanco, S. E. (2012). Structural and Spectroscopic Study of $\mathrm{Al}(\mathrm{III})-3$-hydroxyflavone Complex: Determination of the Stability Constants in Water-Methanol Mixtures. Spectrochim. Acta Part A: Mol. Biomol. Spectrosc. 95, 1-7. doi:10.1016/j. saa.2012.04.034

Dennington, R., Keith, T., and Millam, J. (2016). GaussView, Version 6. Shawnee Mission, KS: Semichem Inc.

Deo, K., Pages, B., Ang, D., Gordon, C., and Aldrich-Wright, J. (2016). Transition Metal Intercalators as Anticancer Agents-Recent Advances. Int. J. Mol. Sci. 17, 1818. doi:10.3390/ijms 17111818
Domagk, G. (1935). Ein beitrag zur chemotherapie der bakteriellen infektionen Dtsch Med. Wochenschr 61, 250-253. doi:10.1055/s-0028-1129486

Dudev, T., and Lim, C. (2000). Tetrahedral vs Octahedral Zinc Complexes with Ligands of Biological Interest: a DFT/CDM Study. J. Am. Chem. Soc. 122, 11146-11153. doi:10.1021/ja0010296

El-Sonbati, A. Z., Diab, M. A., El-Bindary, A. A., Abou-Dobara, M. I., and Seyam, H. A. (2016). Molecular Docking, DNA Binding, thermal Studies and Antimicrobial Activities of Schiff Base Complexes. J. Mol. Liquids 218, 434-456. doi:10.1016/j.molliq.2016.02.072

Emwas, A.-H. M., Al-Talla, Z. A., Guo, X., Al-Ghamdi, S., and Al-Masri, H. T. (2013). Utilizing NMR and EPR Spectroscopy to Probe the Role of Copper in Prion Diseases. Magn. Reson. Chem. 51, 255-268. doi:10.1002/mrc.3936

Fox, C. L., Jr (1977). Zinc Sulfadiazine and its Use in the Treatment of burns. U.S. Patent No. 4,049,802, September 20, 1977.

Frisch, M., Trucks, G., Schlegel, H. B., Scuseria, G. E., Robb, M. A., Cheeseman, J. R., et al. (2009). Gaussian 09, Revision D.01. Wallingford CT: Gaussian. Inc, 201.

Garribba, E., and Micera, G. (2006). The Determination of the Geometry of Cu(II) Complexes: An EPR Spectroscopy Experiment. J. Chem. Educ. 83, 1229. doi:10. 1021/ed083p1229

Gillespie, R. J. (1961). Bond Lengths and Bond Angles in Octahedral, TrigonalBipyramidal, and Related Molecules of the Non-transition Elements. Can. J. Chem. 39, 318-323. doi:10.1139/v61-037

Goodwin, H. A. (1976). Spin Transitions in Six-Coordinate Iron(II) Complexes. Coord. Chem. Rev. 18, 293-325. doi:10.1016/s0010-8545(00)80430-0

Gupta, M., Sharma, R., and Kumar, A. (2018). Docking Techniques in Pharmacology: How Much Promising? Comput. Biol. Chem. 76, 210-217. doi:10.1016/j.compbiolchem.2018.06.005

Gütlich, P., Jung, J., and Goodwin, H. A. (1996). "Spin Transitions in Iron(II) Complexes," in Molecular Magnetism: From Molecular Assemblies to the Devices. NATO ASI Series (Series E: Applied Sciences). Editors E. Coronado, P. Delhaes, D. Gatteschi, and J. S. Miller (Dordrecht: Springer), Vol. 321, 327-378. doi:10.1007/978-94-017-2319-0_13

Haque, M. A., Gandi, A. N., Mohanraman, R., Weng, Y., Davaasuren, B., Emwas, A. H., et al. (2019). A 0D Lead-Free Hybrid Crystal with Ultralow Thermal Conductivity. Adv. Funct. Mater. 29, 1809166. doi:10.1002/adfm. 201809166

Hirata, M., Bamba, T., and Hosoda, S. (1993). The Human colon Cancer Cell Line CaCo-2 Produces Secretory Components during Enterocytic Differentiation. Gastroenterol. Jpn. 28, 528-534. doi:10.1007/bf02776951

Horowitz, H. H., and Metzger, G. (1963). A New Analysis of Thermogravimetric Traces. Anal. Chem. 35, 1464-1468. doi:10.1021/ac60203a013

House, J. E. (2013). Inorganic Chemistry. Amsterdam: Elsevier Inc.

Ibrahim, M. M., Ramadan, A.-M. M., El-Sheshtawy, H. S., Mohamed, M. A., Soliman, M., and I.M. Zayed, S. S. (2015). Synthesis, Characterization and Medical Efficacy (Hepatoprotective and Antioxidative) of Albendazole-Based Copper(II) Complexes - an Experimental and Theoretical Approach. J. Coord. Chem. 68, 4296-4313. doi:10.1080/00958972.2015.1093124

Ismail, L., Rifai, A., Ferronato, C., Fine, L., Jaber, F., and Chovelon, J.-M. (2016). Towards a Better Understanding of the Reactive Species Involved in the Photocatalytic Degradation of Sulfaclozine. Appl. Catal. B: Environ. 185, 88-99. doi:10.1016/j.apcatb.2015.12.008

Jana, K., Maity, T., Mahapatra, T. S., Das Mohapatra, P. K., Debnath, S. C., Das, S., et al. (2017). A Square Pyramidal Copper(II) Complex of a Schiff Base Ligand: Synthesis, crystal Structure, Antibacterial and DNA Interaction Studies. Transit. Met. Chem. 42, 69-78. doi:10.1007/s11243-016-0108-6

Ju, C.-C., Zhang, A.-G., Yuan, C.-L., Zhao, X.-L., and Wang, K.-Z. (2011). The Interesting DNA-Binding Properties of Three Novel Dinuclear Ru(II) Complexes with Varied Lengths of Flexible Bridges. J. Inorg. Biochem. 105, 435-443. doi:10.1016/j.jinorgbio.2010.12.004

Jungwirth, U., Kowol, C. R., Keppler, B. K., Hartinger, C. G., Berger, W., and Heffeter, P. (2011). Anticancer Activity of Metal Complexes: Involvement of Redox Processes. Antioxid. Redox Signaling 15, 1085-1127. doi:10.1089/ars. 2010.3663

Khedr, A. M., and Saad, F. A. (2015). Synthesis, Structural Characterization, and Antimicrobial Efficiency of Sulfadiazine Azo-Azomethine Dyes and Their Bihomonuclear Uranyl Complexes for Chemotherapeutic Use. Turk J. Chem. 39, 267-280. doi:10.3906/kim-1409-21 
König, E. (1971). "The Nephelauxetic Effect Calculation and Accuracy of the Interelectronic Repulsion Parameters I. Cubic high-spin d2, d3, d7, and d8 systems," in Structutal and Bonding. Berlin: Springer, vol 9, 175-212.

Kozlevčar, B. (2008). Structural Analysis of a Series of Copper (II) Coordination Compounds and Correlation with Their Magnetic Properties. Croatica Chem. Acta 81, 369-379.

Lakshmi, S., Endo, T., and Siva, G. (2012). Electronic (Absorption) Spectra of 3d Transition Metal Complexes, in Advanced Aspects of Spectroscopy, 1-41. doi:10. $5772 / 48089$

Lee, Y., Jung, J.-I., Park, K.-Y., Kim, S. A., and Kim, J. (2017). Synergistic Inhibition Effect of TNIK Inhibitor KY-05009 and Receptor Tyrosine Kinase Inhibitor Dovitinib on IL-6-induced Proliferation and Wnt Signaling Pathway in Human Multiple Myeloma Cells. Oncotarget 8, 41091-41101. doi:10.18632/oncotarget. 17056

Márquez, E., Mora, J. R., Flores-Morales, V., Insuasty, D., and Calle, L. (2020). Modeling the Antileukemia Activity of Ellipticine-Related Compounds: QSAR and Molecular Docking Study. Molecules 25, 24. doi:10.3390/ molecules 25010024

Martin, J., Alés, M., and Asuero, A. (2018). An Overview on Ligands of Therapeutically Interest. Pharm. Pharmacol. Int. J. 6, 198-214. doi:10.15406/ ppij.2018.06.00177

Mashat, K. H., Babgi, B. A., Hussien, M. A., Nadeem Arshad, M., and Abdellattif, M. H. (2019). Synthesis, Structures, DNA-Binding and Anticancer Activities of Some Copper(I)-phosphine Complexes. Polyhedron 158, 164-172. doi:10.1016/ j.poly.2018.10.062

Mattar, S. M., Stephens, A. D., and Emwas, A. H. (2002). Generation and Spectroscopic Characterization of the 2,3,5,6-Tetramethoxy-1,4Benzosemiquinone Reactive Intermediate. Chem. Phys. Lett. 352, 39-47. doi:10.1016/s0009-2614(01)01415-4

MOE (The Molecular Operating Environment) (2015). Software Available from Chemical Computing Group Inc. Montreal: 1010 Sherbrooke Street West, Suite 910.Canada H3A 2R7. Available at: https://www.chemcomp.com/Products.htm (Accessed May 1, 2020).

Navarro, M., Vásquez, F., Sánchez-Delgado, R. A., Pérez, H., Sinou, V., and Schrével, J. (2004). Toward a Novel Metal-Based Chemotherapy against Tropical Diseases. 7. Synthesis and In Vitro Antimalarial Activity of New Gold-Chloroquine Complexes. J. Med. Chem. 47, 5204-5209. doi:10.1021/ jm049792o

Panhwar, Q. K., and Memon, S. (2012). Synthesis and Properties of Zirconium(IV) and Molybdate(II) Morin Complexes. J. Coord. Chem. 65, 1130-1143. doi:10. 1080/00958972.2012.668617

Radha, S., KKl, M., and Thamaraichelvan, A. (2016). Elangovana. Synthesis, Characterization and Biological Studies of Sulfadiazine Drug Based Transition Metal Complexes. J. Chem. Pharm. Res. 8, 202-211.

Rahmouni, N. T., Houda Bensiradj, N. E., Megatli, S. A., Djebbar, S., and Baitich, O. B. (2019). New Mixed Amino Acids Complexes of Iron (III) and Zinc (II) with Isonitrosoacetophenone: Synthesis, Spectral Characterization, DFT Study and Anticancer Activity. Spectrochim. Acta Part A: Mol. Biomol. Spectrosc. 213, 235-248. doi:10.1016/j.saa.2019.01.042

Ramírez-Delgado, V., Osorio-Monreal, G., Hernández-Ayala, L. F., Reyes-Vidal, Y., García-Ramos, J. C., Ruiz-Azuara, L., et al. (2015). Electrochemical Behavior of Ni (II) Complexes with N2S2 and N6 Ligands as Potential Catalysts in Hydrogen Evolution Reaction. J. Mexican Chem. Soc. 59, 294-301.

Rani, S., Ajeet, A., and Kumar, A. (2014). Designing of Sulfanilamide/sulfacetamide Derivatives as Human Topoisomerase II Inhibitor: a Docking Approach. Ajps 2, 42-46. doi:10.12691/ajps-2-2-3

Refat, M. S., Sharshar, T., Elsabawy, K. M., El-Sayed, M. Y., and Adam, A. M. A. (2016). Synthesis, Physicochemical Characterization and Anticancer Screening of Sulfa Drug Ruthenium Complexes as Anticancer Agent. J. Mol. Liquids 222, 334-349. doi:10.1016/j.molliq.2016.07.006

Roberts, J. R., Xiao, J., Schliesman, B., Parsons, D. J., and Shaw, C. F. (1996). Kinetics and Mechanism of the Reaction between Serum Albumin and Auranofin (And its Isopropyl Analogue)In Vitro. Inorg. Chem. 35, 424-433. doi:10.1021/ic9414280

Rocha, M., Piro, O. E., Echeverría, G. A., Pastoriza, A. C., Sgariglia, M. A., Soberón, J. R., et al. (2019). $\mathrm{Co}(\mathrm{II}), \mathrm{Ni}(\mathrm{II})$ and $\mathrm{Cu}(\mathrm{II})$ Ternary Complexes with Sulfadiazine and Dimethylformamide: Synthesis, Spectroscopic
Characterization, Crystallographic Study and Antibacterial Activity. J. Mol. Struct. 1176, 605-613. doi:10.1016/j.molstruc.2018.09.008

Rosita, A. S., and Begum, T. N. (2020). Molecular Docking Analysis of the TNIK Receptor Protein with a Potential Inhibitor from the NPACT Database. Bioinformation 16, 387-392. doi:10.6026/97320630016387

Sabolová, D., Kožurková, M., Plichta, T., Ondrušová, Z., Hudecová, D., Šimkovič, M., et al. (2011). Interaction of a Copper(II)-Schiff Base Complexes with Calf Thymus DNA and Their Antimicrobial Activity. Int. J. Biol. Macromol. 48, 319-325. doi:10.1016/j.ijbiomac.2010.12.001

Samsonowicz, M., and Regulska, E. (2017). Spectroscopic Study of Molecular Structure, Antioxidant Activity and Biological Effects of Metal Hydroxyflavonol Complexes. Spectrochim. Acta Part A: Mol. Biomol. Spectrosc. 173, 757-771. doi:10.1016/j.saa.2016.10.031

Santini, C., Pellei, M., Gandin, V., Porchia, M., Tisato, F., and Marzano, C. (2013). Advances in Copper Complexes as Anticancer Agents. Chem. Rev. 114, 815-862. doi:10.1021/cr400135x

Șentepe, I., and Eraslan, G. (2010). Pharmacokinetic of Sulfaclozine in Broiler Chickens. Food Chem. Toxicol. 48, 448-451. doi:10.1016/j.fct.2009.10.044

Shahabadi, N., Hakimi, M., Morovati, T., and Fatahi, N. (2017). DNA Binding Affinity of a Macrocyclic Copper(II) Complex: Spectroscopic and Molecular Docking Studies. Nucleosides, Nucleotides and Nucleic Acids 36, 497-510. doi:10.1080/15257770.2017.1332370

Sharfalddina, A. A., Davaasurenb, B., Emwasb, A-H., Jaremkoc, M., Jaremko, Ł., and Hussien, M. A. (2020a). Single crystal, Hirshfeld Surface and Theoretical Analysis of Methyl 4-Hydroxybenzoate, a Common Cosmetics, Drugs and Foods Preservative - Experiment versus Theory. PLoS One 15, e0239200. doi:10.1371/journal.pone.0239200

Sharfalddina, A. A., Emwasb, A-H., Jaremkoc, M., and Hussien, M. A. (2020b). Transition Metal Complexes of 6-Mercaptopurine; Characterization, DFT Calculation, DNA Binding, Molecular Docking, and Anticancer Activity. Appl. Organomet. Chem. 35 (1), e6041. doi:10.1002/aoc.6041

Sirajuddin, M., Ali, S., and Badshah, A. (2013). Drug-DNA Interactions and Their Study by UV-Visible, Fluorescence Spectroscopies and Cyclic Voltametry. J. Photochem. Photobiol. B: Biol. 124, 1-19. doi:10.1016/j.jphotobiol.2013. 03.013

Sirajuddin, M., Ali, S., Haider, A., Shah, N. A., Shah, A., and Khan, M. R. (2012). Synthesis, Characterization, Biological Screenings and Interaction with Calf Thymus DNA as Well as Electrochemical Studies of Adducts Formed by Azomethine [2-((3,5-dimethylphenylimino)methyl)phenol] and Organotin(IV) Chlorides. Polyhedron 40, 19-31. doi:10.1016/j.poly.2012.03.048

Slade, R., Tomlinson, A., Hathaway, B., and Billing, D. (1968). The Electronic Properties of Trigonal Bipyramidal Complexes of the Copper (II) Ion. J. Chem. Soc. A: Inorg., Phys., Theor. 61-63.

Stober, H., and DeWitte, W. (1982). Sulfadiazine. Anal. Profiles Drug Subst., 523-551. doi:10.1016/s0099-5428(08)60274-9

Sweeney, E. E., McDaniel, R. E., Maximov, P. Y., Fan, P., and Jordan, V. C. (2012). Models and Mechanisms of Acquired Antihormone Resistance in Breast Cancer: Significant Clinical Progress Despite Limitations. Horm. Mol. Biol. Clin. Invest. 9, 143-163. doi:10.1515/hmbci-2011-0004

Tabassum, S., Zaki, M., Ahmad, M., Afzal, M., Srivastav, S., Srikrishna, S., et al. (2014). Synthesis and crystal Structure Determination of Copper(II)-complex: In Vitro DNA and HSA Binding, pBR322 Plasmid Cleavage, Cell Imaging and Cytotoxic Studies. Eur. J. Med. Chem. 83, 141-154. doi:10.1016/j.ejmech.2014. 06.018

Vahdati, R. F., Housaindokht, M. R., Jalal, R., Eshtiagh, H. H., Verdian, D. A., and Sadeghi, G. S. (2014). Spectroscopic and Molecular Modeling Based Approaches to Study on the Binding Behavior of DNA with a Copper (II) Complex. J. Fluoresc 24, 1225-1234. doi:10.1007/s10895-014-1405-0

Van de Loosdrecht, A. A., Beelen, R. H. J., Ossenkoppele, G. J., Broekhoven, M. G., and Langenhuijsen, M. M. A. C. (1994). Ossenkoppele G, Broekhoven $\mathrm{M}$ and Langenhuijsen MA Tetrazolium-Based Colorimetric MTT Assay to Quantitate Human Monocyte Mediated Cytotoxicity against Leukemic Cells from Cell Lines and Patients with Acute Myeloid Leukemia. J. Immunol. Methods 174, 311-320. doi:10.1016/ 0022-1759(94)90034-5

Wong, E., and Giandomenico, C. M. (1999). Current Status of Platinum-Based Antitumor Drugs. Chem. Rev. 99, 2451-2466. doi:10.1021/cr980420v 
Yang, X.-L., Liu, J., Yang, L., and Zhang, X.-Y. (2005). Synthesis, Characterization, and Susceptibility of Bacteria of Selenium Dioxide Complexes with Sulfadrugs. Synth. Reactivity Inorg. Metal-Organic, Nano-Metal Chem. 35, 761-766. doi:10. 1080/15533170500359620

Zagouri, F., Sergentanis, T. N., Chrysikos, D., Papadimitriou, C. A., Dimopoulos, M.-A., and Psaltopoulou, T. (2013). Hsp90 Inhibitors in Breast Cancer: a Systematic Review. The Breast 22, 569-578. doi:10.1016/ j.breast.2013.06.003

Zehra, S., Roisnel, T., and Arjmand, F. (2019). Enantiomeric Amino Acid Schiff Base Copper(II) Complexes as a New Class of RNA-Targeted MetalloIntercalators: Single X-ray Crystal Structural Details, Comparative In Vitro DNA/RNA Binding Profile, Cleavage, and Cytotoxicity. ACS Omega 4, 7691-7705. doi:10.1021/acsomega.9b00131

Zeng, Y.-B., Zhu, S.-H., Dong, H., Han, H.-Y., Jiang, L.-L., Wang, Q., et al. (2012). Great Efficacy of Sulfachloropyrazine-Sodium against Acute Murine Toxoplasmosis. Asian Pac. J. Trop. Biomed. 2, 70-75. doi:10.1016/s22211691(11)60193-7
Zhao, Z., Zhou, X., Zhang, W., and Zhao, W. (1992). Textbook of Instrument Analyses. Beijing: Higher Education Press.

Conflict of Interest: The authors declare that the research was conducted in the absence of any commercial or financial relationships that could be construed as a potential conflict of interest.

The handling editor declared a shared affiliation, though no other collaboration, with the authors $\mathrm{AE}$ and MJ.

Copyright $\odot 2021$ Sharfalddin, Emwas, Jaremko and Hussien. This is an open-access article distributed under the terms of the Creative Commons Attribution License (CC $B Y)$. The use, distribution or reproduction in other forums is permitted, provided the original author(s) and the copyright owner(s) are credited and that the original publication in this journal is cited, in accordance with accepted academic practice. No use, distribution or reproduction is permitted which does not comply with these terms. 